\title{
The economic impact of technological procurement for large-scale research infrastructures: Evidence from the Large Hadron Collider at CERN
}

Authors: Paolo Castelnovo ${ }^{1}$, Massimo Florio ${ }^{1 *}$, Stefano Forte ${ }^{2}$, Lucio Rossi ${ }^{3}$, Emanuela Sirtori ${ }^{4}$

\begin{abstract}
The Large Hadron Collider at CERN, the European Organisation for Nuclear Research, is the world's highest-energy particle accelerator. Its construction (1995-2008) required frontier technologies and close collaboration between CERN scientists and contracting firms. The literature on "Big Science" projects suggests that this collaboration generated economic spillovers, particularly through technological learning. CERN granted us access to its procurement database, including suppliers of LHC from 35 countries for orders over 10,000 Swiss Francs. We gathered balance-sheet data for more than 350 of these companies from 1991 to 2014, which include the years before and after that of the first order received. The study assesses, in quantitative terms, whether becoming a CERN supplier induced greater R\&D effort and innovative capacity, thus enhancing productivity and profitability. The findings - which controlled for firms' observable characteristics, macroeconomic conditions, and unobserved time, country, industry and firm-level fixed effects - indicate a statistically significant correlation between procurement events and company R\&D, knowledge creation and economic performance. The correlation is chiefly driven by high-tech orders; for companies receiving non-hightech orders, it is weaker, or even statistically not significant.
\end{abstract}

JEL: O30, O33, Q55

Keywords: public procurement, CERN, Large Hadron Collider, technological spillovers.

\footnotetext{
Affiliations:

${ }^{1}$ Department of Economics, Management, Quantitative Methods, Università degli Studi di Milano.

${ }^{2}$ TIF Lab, Department of Physics, Università degli Studi di Milano and INFN, Sezione di Milano.

${ }^{3} \mathrm{CERN}$ - Accelerator \& Technology Sector, Geneva, CH, and Department of Physics, Università degli Studi di Milano.

${ }^{4}$ CSIL Centre for Industrial Studies, Milano.

*Correspondence to: massimo.florio@unimi.it
}

\section{Introduction}


"Big Science" projects are expensive and the ultimate social impact of discovery is hard to predict, especially where basic research is concerned (Martin and Tang 2007; Bornmann 2012, 2013; Godin and Dorè 2012). It may take decades to understand how knowledge of fundamental features of nature could be of any practical use, and in the meantime governments are expected to support investment in science in hopes of highly uncertain social returns. But there also exist immediate benefits that are observable even during the construction of a large research infrastructure (Salter and Martin 2001). Some of these benefits stem from unprecedented technological challenges in meeting the exacting standards of cutting-edge experimental devices that demand close collaboration between laboratories and firms in the supply chain of machines that serves for scientific discovery. Such collaboration may generate learning effects that spill over from basic research as a positive externality to firms thanks to procurement contracts. Technological learning can help firms generate and process innovation and ultimately increase their growth opportunities (Turner, 2015).

We have studied this effect in relation to CERN, the European Organisation for Nuclear Research. CERN is the world's leading particle physics laboratory and its role and impact have been extensively studied by economists, from the three papers of Martin and Irvine (1984a, 1984b, 1984c) to more recent work by the OECD (2014). CERN hosts the Large Hadron Collider (LHC), where the Higgs boson was discovered in 2012. The LHC, built between 1993 and 2008, consists of a 27kilometer underground ring between Switzerland and France. Particle beams are collided at four points where detectors are located, each of which is operated by an experimental "collaboration", a team involving CERN staff as well as scientists from universities and research institutes from various countries. In their observations, the four detectors produce enormous amounts of data per second that is transmitted to a series of computing nodes around the world, which are connected through the worldwide LHC computer grid. The LHC is indeed, like the title of L.R. Evans' book, a "marvel of technology" (Evans, 2009).

The technological features of the LHC are extremely demanding. CERN, its collaborators, and firms with procurement contracts have had to closely cooperate to solve entirely new problems in a series of fields, including superconductivity, cryogenics, electromagnets, ultra-high vacuum, distributed computing, rad-resistance materials, and fast electronics (Evans 2009; Giudice, 2010). The large number of suppliers, the international scope of procurement, the wide range of sectors, and the duration of the construction process offer an ideal setting for our central research question: namely, how best to measure the economic impact of technological procurement on the performance of suppliers in Big Science.

In fact, when the introduced innovation is so radical as to constitute a discontinuity, it may generate technological advances that pervade many sectors and have a protracted impact on the entire 
economic system. Such innovations, described as "General Purpose Technologies" (GPTs), have been investigated, among others, by Bresnam and Trajtenberg (1995), Helpman (1998), and Janovic and Russeau (2005). The World Wide Web, invented at CERN in 1989, in addition to being perhaps the most famous example of technological spillover from Big Science, is a notable example of GPT breakthrough.

More in general, there is clear, albeit unsystematic, evidence that the firms working for CERN have learned new solutions and then developed new products for other customers outside of the scientific field (see for instance Amaldi 2012; Nielsen and Anelli, 2016). Examples in the medical sector include hadrontherapy (Battistoni et al., 2016) and the new open source software "TIGRE" (Tomographic Iterative GPU-based Reconstruction) for PET scanners. As regards transportation, one of CERN's suppliers for ultra-high vacuum technology was able to partner with Hyperloop Transportation Technology, a company that is developing a very high, even ultrasonic, speed transport system thanks to the know-how and experience that was acquired while working on the LHC . "VESPER" (Very energetic Electron facility for Space Planetary Exploration missions in harsh Radiative environments) found application in the aerospace industry. The potential applications of "KRYOLIZE", a novel cryogenic software for sizing relief valves that protect against overpressure, also interest the food industry. Superconductivity, a core feature of the magnets developed to steer the LHC particle beams, may find application in various fields, ranging from medicine, with "particle therapy,"2 to aerospace, with hybrid propulsion systems, to agriculture, with fruit sorting machines, to energy, with Uninterruptible Power Supply (UPS) systems ${ }^{3}$ (see Aschauer et al. 2017).

Three different approaches have been taken to gauging the economic effects of technological learning stemming from a procurement relationship with large basic research infrastructures (Salter and Martin 2001; Hall et al., 2010; Autio et al, 2004): case studies, surveys, and input-output or other aggregate statistical methods. Detailed case histories provide interesting qualitative insights into suppliers' learning effects and subsequent commercial developments (Arenius and Boisot, 2011; OECD, 2014). Case studies on the impact of research have been used extensively in the U.K. as part of a unique assessment exercise including 7,000 case studies (Van Noorden, 2015).

Surveying stakeholders is another helpful approach. A survey of CERN suppliers (Autio, 2014) found that collaboration with CERN was instrumental to product innovation, new R\&D, starting a new business unit, or opening a new market, and that more than $40 \%$ of the respondent firms reported that after the contract they were more internationalised and had benefited from

\footnotetext{
${ }^{1}$ https://kt.cern/success-stories/hyperloop

2 "Particle Therapy" is a variant of radiotherapy that irradiates tumor tissue with protons and light ions (Aschauer, 2017: 15).

3 "UPC systems are devices for energy storage that can deliberately take on and deliver power when necessary" (Aschauer, 2017: 2).
} 
technological learning. The average combined value of suppliers' sales to other clients and cost savings was reported to be three times the amount of the CERN order. Florio et al. (2017) report the findings of a recent survey of over $600 \mathrm{CERN}$ suppliers, confirming lasting effects on performance, organisation, and behaviour.

Finally, aggregate statistical approaches have been adopted for decades to study the effects of scientific programs ranging from NASA (Bezdek and Wendling, 1992) to biotechnology (Webb and Whyte, 2009). Typically, input-output tables of average national or regional inter-industry linkages and investment multipliers were used to compute the impact of research spending by an agency or project on GDP or productivity.

All three approaches are informative, but none provides a true empirical measurement, strictly speaking, of the direct effects of procurement on suppliers: case studies, with their specific histories, are unavoidably heterogeneous in method, including narrative and other qualitative approaches; surveys of company managers provide some statistical evidence but are likely to be affected by selfselection as well as respondents' judgment and memory; input-output models and other aggregate econometric approaches heavily depend on certain macroeconomic assumptions (Macilwain, 2010), in that they apply average output and employment multipliers that are used for the entire economy, which may or may not be relevant for contracting firms in Big Science projects.

Our empirical strategy is innovative: we consider the procurement contract between a firm and its client, i.e. the institution that manages the research infrastructure, as an event whose effects can go beyond the immediate impact (i.e. the first order received) to change the firm's performance over time, even net of confounding factors such as macroeconomic conditions. In this perspective, we apply firm-level panel microeconometrics to study the long-run effects of CERN procurement on suppliers' R\&D activity, knowledge production, productivity, and - ultimately - profitability. This approach is replicable for any other Big Science project in principle.

CERN granted us access to the LHC procurement data from 1995 to 2008. There were 1296 suppliers with at least one order of over SFR 10,000, for a total of 11,969 orders. Orders went to firms in 35 different countries including China, Japan, Russia, and the United States, but over 99\% of the orders, based on their value, were placed with European firms, mostly in CERN member states, which are preferred in CERN procurement. We recorded the location, year, order value, and activity code of each supplier. We then classified each order on a technology intensity scale.

From the original list of LHC suppliers (which included other laboratories, joint ventures, etc.) we selected those whose core financial indicators were available in a public database (Amadeus or Orbis) for the 1991-2014 period, which is a sufficiently long time to empirically test the impact of the procurement contracts. We also wanted to identify patents that had been filed by the same firms 
by using the Patstat database. Some 360 companies satisfied these criteria, giving us a sample that produced from 3300 to 5800 observations, depending on which dependent variable was considered.

Our hypothesis is that becoming a CERN supplier may induce more intensive effort in R\&D and knowledge creation, leading to improvements in productivity and profitability, especially for high-tech suppliers. We build on the framework of Crépon et al. (1998), augmented by the impulse variable, consisting in the date of the first order by CERN.

To test the chain of consequences from the procurement event, our causal variable, to the sequence of R\&D investments, patent filing, productivity gains and - ultimately - higher profitability, as a first step we built a set of single-equation empirical models where we test whether a CERN procurement effect is detectable at each step of the logical chain. After controlling for firm characteristics, such as assets and other size variables, time and country-fixed effects (as well as industry ones when appropriate), and macroeconomic factors, we found that being an LHC supplier is correlated with yearly changes in our empirical proxies for each item in the logical chain. CERN orders are correlated with changes in suppliers' intangible assets, increases in the number of patent filings, changes in labour productivity, and ultimately increases in longer-term revenue and profitability. The estimated coefficients of this "CERN effect" are statistically significant for the whole sample but higher for high-tech firms. As expected, in line with the intuitions implied by the surveys reported by Autio (2014) and Florio et al. (2017), in most cases the coefficients are not significant for firms receiving orders for "off-the-shelf" products.

As a second step, following the most recent developments of the literature (see e.g. Hall and Sena 2017; Van Leeuwen and Mohnen, 2017) we estimated our model as a system of simultaneous equations.

The paper is structured as follows. Section 2 discusses the literature and introduces our conceptual framework and hypotheses. Section 3 presents the data and section 4 describes the empirical strategy: section 4.1 defines the single-equation regression models, while section 4.2 introduces the system of simultaneous equations. Section 5 presents the estimation results, while section 6 tests them through several robustness checks, and section 7 concludes with a discussion of the findings and their policy implications.

\section{Earlier literature and the conceptual framework}

In this section, we briefly review some relevant strands of literature. First, we recall the Arrow-Solow mechanism of learning externality through problem-solving (2.1). Then we cite some evidence of spillovers from universities and public research centers to firms (2.2) and public procurement for 
innovation (2.3). Finally, drawing on these earlier studies, we formulate our own research question and working hypotheses (2.4).

\subsection{Learning spillovers: concepts and measurement}

Learning spillovers are externalities that stem from non-rivalrous and partially excludable knowledge creation (Griliches, 1979; Romer, 1990; Foray, 2004). To cite Kenneth Arrow's seminal thesis: "Learning is the product of experience. Learning can only take place through the attempt to solve a problem and therefore only takes place during activity.... [L]earning associated with repetition of essentially the same problem is subject to sharply diminishing returns" (Arrow, 1962, p. 155).

In our context, the key concept here is "attempt to solve a problem," insofar as basic research infrastructures (RIs) pose unprecedented problems to the firms that construct them. The formal model initially proposed by Arrow, which posited increasing returns to cumulative gross investment, was instrumental in creating an endogenous theory of growth in macroeconomics, but the thesis of learning-by-doing ultimately depends on microeconomic, firm-level mechanisms. Thompson (2010) reviewed some of the empirical literature and concluded that passive learning was not as important as had been expected and that other mechanisms were therefore presumably at work. Irwin and Klenow (1994), in a study of the semiconductor industry, concluded that under normal market circumstances of cumulative knowledge accumulation, learning spillovers may be limited (see also Nemet, 2012, on wind power projects).

Solow (1997) expanded Arrow's original model to comprise discontinuous innovation arising from experience related to new investments. For a firm, solving a new problem requires more $R \& D$ investment and innovation. Product and process innovation then spurs productivity and may generate changes in output prices and profit margins through the Schumpeterian mechanism of temporary monopoly. Several theoretical models of innovation based on this mechanism have been proposed (Stokey, 1988, for one).

Two main methods have been employed to estimate the magnitude of R\&D spillovers from an empirical perspective. The "technological flow" approach positions firms or industries within a matrix of technological linkages, using either input-output or technology matrices based on patent data. The spillovers from the R\&D activities of one firm/industry onto others are examined (see among others Terleckyj, 1974 and 1980, and Scherer, 1982 and 1984). The "cost function" method is an econometric approach, estimating the impact of spillovers on the cost and production structure of the receiving firms/industries (see e.g. Bernstein, 1988, and Bernstein and Nadiri, 1991). For an extensive review of studies using these two alternative procedures, see Nadiri (1993). 


\subsection{Spillovers from research centres and universities}

According to Bernstein and Nadiri (1991), in the case of private firms' relations with non-market organisations, such as universities and research centres, the learning spillovers are enhanced. As CERN is both a publicly funded institution and a research hub for thousands of academics through collaborations, a relevant strand of literature is that on the transmission of knowledge to firms in this context. The seminal paper of Jaffe (1989) empirically demonstrates the existence of spillovers from university research to business innovation that measured by corporate patents. The beneficial sideeffects of academic research are also found in business start-ups (Bania et al., 1993) and hightechnology innovations (Anselin et al., 1997). Mansfield demonstrated that a significant portion of firms' product and process innovation in the U.S. would have been impossible, or at least substantially delayed, in the absence of university research (Mansfield 1991, 1998). And the closer firms are to major academic research centres, the greater the benefits will be (Mansfield and Lee, 1996). More recently, Helmers and Overman (2017) have discussed the correlation between proximity to the Synchrotron Diamond Light Source in the U.K. and the productivity of academic research. Publicly funded basic research at universities does not substitute private $R \& D$, but rather stimulates and enhances it (Nelson and Rosenberg, 1994). Studies showing a significant contribution of academic research to economic growth include Bergman (1990) and Martin (1998). The following different types of contribution to growth are identified by Salter and Martin (2001): increase in the stock of information, new instrumentation and methodologies, skilled graduates, professional networks, technological problem-solving, and the creation of new firms. Starting from this taxonomy, our focus is mainly on technological problem-solving and new instrumentation.

\subsection{Public procurement and innovation}

Procurement is a possible source of learning that stems from discontinuous innovation in the ArrowSolow acceptation, as information between the contracting parties ex-ante is never symmetrical and requires a delicate balancing of risks and incentives (Bajari and Tadelis, 2001). Procurement itself has accordingly been described as a learning process (Newcombe, 1999), and public procurement, in particular, has been studied as a driver of innovation (Edquist et al., 2105; Edquist and ZabalaIturriagagoitia, 2012). Edquist and Hommen (2000, pp. 5) defined public procurement for innovation (PPI) a situation in which "a public agency places an order for a product or system which does not exist at the time, but which could (probably) be developed within a reasonable period. Additional or new technological work is required to fulfill the demand of the buyer."

Public procurement is also considered as an important demand-side innovation policy (Aschhoff and Sofka, 2009; Martin and Tang, 2007), particularly when the development of 
sophisticated products is required (Salter and Martin, 2001). For this reason, the role of PPI in promoting radical innovations (including General Purpose Technologies) is relevant in economic fields characterised by high risk that cannot be borne entirely by the private sector (Mazzuccato, 2016). A concrete example concerns Swedish military jets (Eliasson, 2010, 2011): the development of a new aircraft involved a complex network of suppliers and close public-private cooperation, leading the aircraft industry to become a "technical university" where continuous learning occurs. PPI has a positive effect on firms' R\&D investment, with a demand-pull effect that is greater than that of other private contracts (Litchtenberg, 1988) and is a possible completion/addition/accessory or even an alternative to supply-side policies (Edler and Georghiou, 2007). Guerzoni and Raiteri (2015) show that PPI has a major impact on firms' expenditure in innovative activities that is stronger than that of R\&D subsidies and tax credits.

The context of procurement contracts for large-scale research infrastructures is considered by Autio et al. (2003) and Purton (2015). Important insights are also offered by Salter and Martin (2001); for a more general discussion see Stephan (1996) and Price (1984). For qualitative case studies, see inter alia Fahlander (2016) on the impact of two accelerators (HIE-ISOLDE and ESS) on local firms, Pero (2013) on three accelerators for material science (Elettra Synchrotron in Trieste, ESRF synchrotron in Grenoble, and XFEL in Hamburg), and OECD (2014) with a specific focus on LHC magnets, a core feature of the accelerator that is discussed in some detail by Rossi and Todesco (2009), and hadron therapy (Battistoni et al., 2016).

For approaches to measuring the socio-economic impact of RIs through input-output modeling or other aggregate methods, see HAL Innovation Policy Economics (2013) on the TRIUMF particle physics laboratory in Canada, and Garcia-Montalvo and Raya (2010) on the ALBA synchrotron in Barcelona.

Previous research on the economic repercussions of CERN procurement mainly drew on surveys of suppliers. This literature stressed industrial knowledge spillovers (Schmied, 1977; Bianchi-Streit et al., 1984; Autio et al., 2003; Autio et al., 2004; Autio, 2014) and considered the important role of CERN itself as a risk-taker in the realisation of complex scientific projects (Unnervik, 2009). Autio et al. (2003) was based on a survey of 154 suppliers (1997-2001), representing around half of CERN's total procurement budget in those years. The main findings are the following: $38 \%$ of the suppliers designed new products, $13 \%$ created new R\&D teams, $14 \%$ created a new business unit, $17 \%$ entered new markets, $42 \%$ reported increased international operations, $44 \%$ reported technological learning, and 36\% said there was market learning. Previous research at CERN (Bianchi-Streit et al., 1984) related to the construction of the SPS accelerator (1963-1987) was also based on interviews with suppliers (160 out of 519 providing high-tech 
components). It was found that the "utility ratio" (increased revenue + cost savings)/(procurement value) was in the range of 3:1, meaning that each franc that was spent by CERN in procurement generated three francs worth of additional value to the suppliers. Aberg and Bengtson $(2015,2016)$, in two recent papers, critically examine the CERN procurement process as an innovation driver, based on about 100 interviews. Florio et al. (2017) update the survey methodology by means of a Bayesian Network Analysis of the outcomes of being a CERN supplier for over 600 firms (their findings are compared with ours in the concluding section). Qualitatively interesting as they may be, all these contributions depend on surveys of firm managers, which may be affected by respondents' selfselection and possibly subjective bias.

\subsection{Research question and hypotheses}

We framed our research question and working hypotheses in the light of this relevant literature. CERN operates as a "learning-environment" for its suppliers and poses new problems to be solved as well as, potentially, an Arrow-Solow discontinuity. Our aim is to conduct an empirical test, controlling for firm-specific and context-specific effects, of whether this environment actually produces measurable effects on suppliers' innovation outcomes and economic performance - as is widely acknowledged by earlier studies using the qualitative, narrative, case-study and managerial survey approaches.

The logic underlying this question follows the chain of events highlighted by Crépon et al. (1998), which singles out firms' research activity as a determinant of innovation output, which in turn impacts on productivity. ${ }^{4} \mathrm{We}$ extended this framework by introducing procurement, which we posit as the trigger that influences firms' $R \& D$, innovation, and productivity at the beginning of the chain and ultimately leads to gains in revenues and profitability. Thus the full sequence of events we tested is:

\section{Procurement relation $\rightarrow$ increase in $R \& D \rightarrow$ innovations $\rightarrow$ productivity growth $\rightarrow$ change in revenues and profitability}

In other words, we applied empirical proxies to investigate the impact of procurement on firms' knowledge production and innovation capacity (section 5.1) and on their economic performance, gauged by productivity and profitability (section 5.2).

Within this framework, we tested two straightforward hypotheses:

\footnotetext{
${ }^{4}$ We thank an anonymous reviewer for this suggestion.
} 
Hypothesis 1: Receiving an order from CERN enhances suppliers' knowledge production and innovation outcomes, measured through $R \& D$ effort and patents.

Hypothesis 2: Becoming a CERN supplier increases firms' performance in terms of productivity, revenue and profits, regardless of the initial order.

As the assets required by the RI are of varying technological intensity, a second question is whether the effect we are looking for is correlated with the high-tech intensity of the order, i.e. with the knowledge embodied, possibly through a cooperative R\&D effort, formal or informal, between the RI and the supplier firm's staff, as suggested by Autio et al. (2003). We expect any learning mechanism to be more closely correlated with the performance of firms meeting high-tech orders (i.e., those that require a certain degree of problem-solving, as per Arrow-Solow) and less with that of suppliers of off-the-shelf products.

However, another possible explanation for the correlation between subsequent sales and procurement relationship involves a reputation effect. One might expect that, in terms of marketing, the quality of the product or the reliability of the firm can be evinced simply by having been selected by a prestigious customer like CERN. For example, suppliers of staples to royal houses (which are supposedly selective in terms of quality) advertise this fact to increase their visibility (in the U.K., for example, there are over 680 Royal Warrant holders “by appointment of HM The Queen”). If there is a pure reputation effect for CERN suppliers, we should find that not only firms supplying new products, but also those supplying standard ones, benefit. Accordingly, if the technological or market learning effect mainly works for high-tech suppliers, and reputation or other generic effects work for all of them, we should find a positive correlation between profits and procurement events in both cases, with a stronger one for high-tech suppliers, given the presumed cumulative effect of two drivers.

This lead to the formulation of a further, complementary hypothesis for testing:

Hypothesis 3: The correlation between procurement events and firms' subsequent performance is stronger for suppliers of high-tech orders than for those of non-high-tech orders.

Clearly, these three hypotheses collapse a complex story into a set of simple propositions, while the actual behavioral change within a firm may be more nuanced. For example, some innovations may stem from organisational changes and managerial adjustments spurred by the firm's exposure to the CERN environment, as some managerial surveys suggest (particularly Autio et al, 2003, Florio et al., 2017). However, these more complex qualitative effects are best captured by case studies or surveys, whereas our objective is to produce a quantitative estimate of the average CERN effect on suppliers; for this reason, some simplifying hypotheses are necessary. 


\section{The data}

Our main source of firm-level data is the CERN Procurement and Industrial Services (PI) Group (http://procurement.web.cern.ch/procurement-strategy-and-policy), the team in charge of coordinating all the supplies and services that the laboratory needs. Experimental collaborations, such as ATLAS and CMS, have some procurement autonomy, so their orders are not covered here, except when they are directly managed by CERN. The PI team regularly monitors and reports all supply activities to management and CERN member states (MS). The PI makes or authorises major purchases, with three main objectives: (i) to make sure that contracts satisfy technical and financial requirements; (ii) to keep costs as low as possible; and (iii) to achieve balanced industrial returns for member states. Ensuring a certain distribution of contracts among MS is crucial: a strong political push to institute a mechanism to guarantee a "fair return" on investments for all MS resulted in the approval of a set of procurement rules in 1993 (Åberg and Bengtson, 2015; CERN, 1993a,b). Depending on their type, contracts are awarded on either a "lowest compliant" or "best value for money" basis. However, "lowest compliant" contracts for over SFR 100,000 are subjected to a further requirement, namely the overall achievement of "well-balanced industrial return coefficients" for MS. A country is considered to be in line if its return coefficient - i.e. the ratio of its percentage of the value of all contracts in the course of the preceding four calendar years to its percentage contribution to the CERN budget - is above a certain threshold. CERN has various tools to ensure well-balanced returns, such as "limited tendering" and "alignment" (see CERN, 2015: 37-42). The former restricts the tender to MS with very low return coefficients, while the latter gives priority to firms in poorly-balanced countries with less than their balanced share of contracts.

In 2015 and 2016 the CERN PI provided us with several extracts from the full dataset of orders for the construction of the LHC. The considered period is 1995-2008, i.e. before the accelerator started operating regularly. Only orders over SFR 10,000 were included, as we wanted to exclude a welter of marginal suppliers for which knowledge or reputation/generic effects are unlikely.

The original LHC procurement dataset we received contained 1296 suppliers. We were able to identify 1060 of them in the Orbis and Amadeus databases. Some are not recorded by Orbis because they are other research institutes, such as the Russian Academy of Sciences, consortia, or other organisations that do not publish their accounts. Furthermore, we need the accounting data for periods before and after the procurement event, and for some companies data dating back more than twenty years are not available. National laws on corporate balance-sheet disclosure also vary. For example, Swiss companies, which accounted for $30 \%$ of our initial sample of CERN suppliers, are not subject to any legal requirement to release their accounting data, and no financial data on any of them are 
available in Amadeus or any other public repository. Similarly, German firms seldom report information on their balance sheets. Visual inspection of procurement data and interviews to CERN staff suggest that firms for which financial data are not available do not differ systematically from those with adequate data in ORBIS. Nevertheless, by filtering the initial sample on this basis, we managed to create a subsample of 365 companies about which an adequately long financial history is available.

Figure 1 shows the distribution over time of the orders that were assigned in the restricted sample, as well as the number of new suppliers and initial procurement events, which is our variable of interest, as it marks the starting point of firms' collaboration with CERN for the LHC project.

\section{Fig. 1 - Yearly distribution of LHC procurement orders, first-time orders to a supplier and new suppliers in our sample}

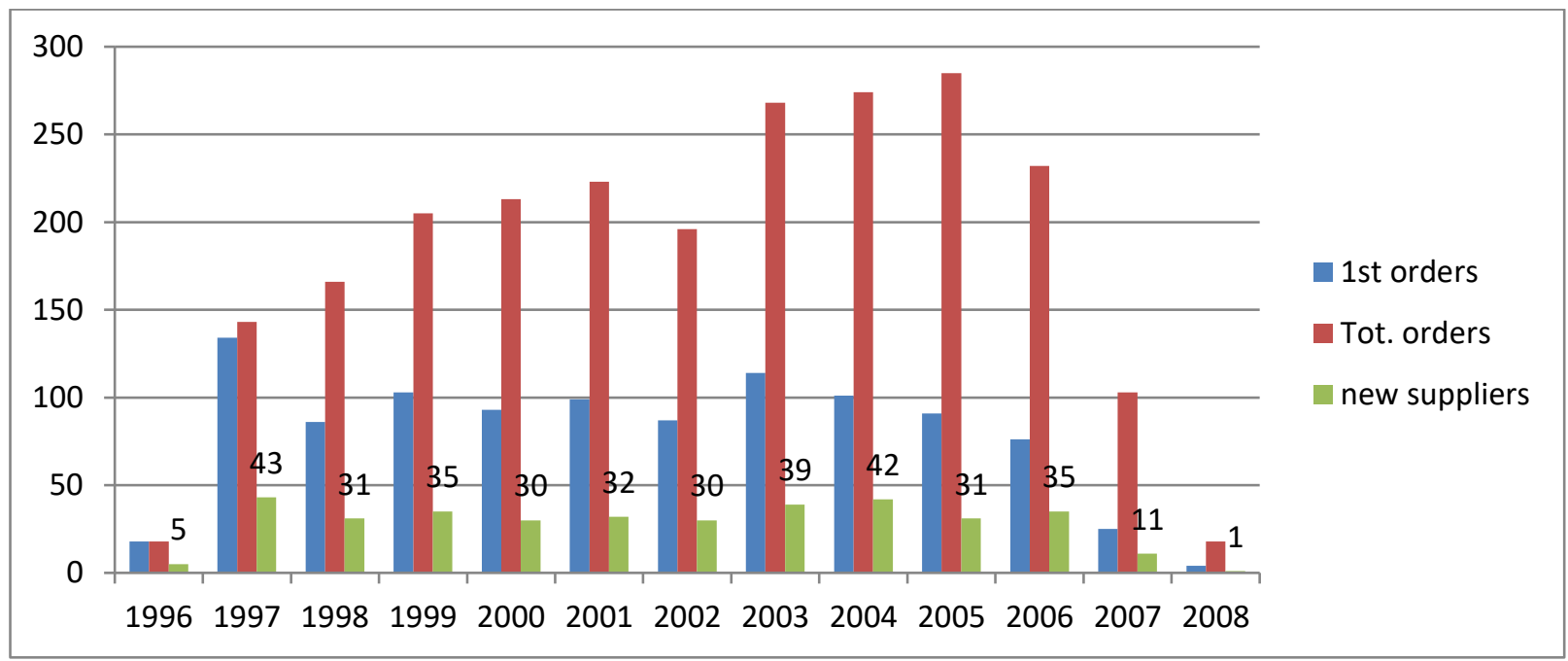

Source: Authors' elaboration based on CERN data.

Each of these first-time orders, which are our initial events, marks the beginning of a potential learning process and/or reputation effect for a specific firm. This is our variable of interest, modeled as a simple binary code taking value 0 before and 1 after the year of the first order (further on, we also apply other definitions as a robustness check). The subsequent time profile is informative: the average number of years in which a company received at least one order is 2.2 (standard deviation 1.87 , with a minimum of 1 and a maximum of 11 years). This implies that the direct impact of the orders on company profitability could not last more than 2 or 3 years, on average. However, we are interested in economic effects stretching beyond these initial years. The first-year events in our study are evenly spread between 1996 and 2007 (unlike the total orders, which peak in 2003-2005). Around 90 new suppliers were involved in the LHC in any of the 12 years considered. 
This empirical analysis exploits the fact that, unlike most event studies, we have not one, but a sequence of twelve "before-after" events. For example, a company entering the CERN procurement system in 2000 can potentially be observed for 10 years before the event (including 2000), and 14 years after (as we have financial data from 1991 to 2014). For a company entering in one of the last groups, e.g. 2007, we have potentially 7 years of observations "after" and 18 years "before" the event.

Over $90 \%$ of the LHC suppliers in the original CERN database are located in six countries: France, Switzerland, Germany, Italy, the U.K. and Spain. In our final sample, the majority also come from these countries, with the important exception of Switzerland, which is not represented, for the reason cited above. In our sample, suppliers are located in 18 different countries, all in the European Union. France is by far the most heavily represented (53.4\% of the total), followed by Italy (14\%), the U.K. (8.2\%), Spain (5.8\%) and Germany (4.4\%). ${ }^{5}$

As previously pointed out, our sample only comprises CERN suppliers whose financial data are available in the Amadeus or Orbis databases, the former covering only European and the latter also non-European companies. Moreover, although our final sample consists solely of European firms, a few turned out to be reported in Orbis but not in Amadeus, so we decided to use both sources. Using these two databases, we searched for six company performance variables between 1991 and 2014, namely: intangible assets, number of patents filed, sales per employee (proxying for productivity), and three profitability measures, EBIT (Earnings before Interest and Taxes), operating revenue, and the EBIT margin, i.e. EBIT over operating revenue.

Two of the companies (ENEL and Electricitè de France) are evident outliers in size, as measured by sales, revenue, EBIT or total assets so we excluded them from the sample. ${ }^{6}$

Table 1 shows summary statistics for explanatory and dependent variables in regressions. Patents obtained from Patstat comprise a much larger number of observations than financial variables, because Patstat has data on all 1060 companies in our original dataset, while the financial variables are missing from many observations. The statistics refer to companies that reported relevant financial information at least once. Ultimately, however, we also had to drop suppliers that did not report financial data both before and after the year of the initial procurement. Clearly, exclusions reflect the lack of different variables, and as a consequence our company samples vary with the dependent variable estimated. ${ }^{7}$ Here we present statistics for the entire sample, but these considerations also hold for each of the various analysed samples.

\footnotetext{
5 The other countries are: Finland $(2.74 \%, 10$ companies), Belgium $(2.19 \%, 8)$, Sweden $(1.64 \%, 6)$, the Czech Republic and the Netherlands $(1.37 \%, 5)$, Denmark and Portugal $(1.1 \%, 4)$, Austria $(0.82 \%, 3)$, Poland and Slovakia $(0.55 \%, 2)$, Bulgaria, Ireland and Russia $(0.27 \%, 1)$.

${ }^{6}$ Including them in the econometric analysis, however, does not noticeably change the results.

7 A company may report information both before and after the initial procurement year only in reference to some of the financial variables and not others. To avoid reducing the sample size excessively, we preferred to work with slightly different samples rather than limit ourselves to only analysing companies with no missing values in any of the outcome variables.
} 
As is often the case with accounting data, the nominal variables exhibit a heavily skewed distribution, reflecting the standard pyramid structure of the industry sector. However, the "EBIT margin" variable, as a ratio, is immune to this problem: the median values are not far from the means, revealing a rather symmetrical distribution.

As regards patenting, $69.3 \%$ of the companies (732 out of 1060) did not file any patent during our sample period, which explains the low mean and nil median given in Table 1, thus justifying the use of count data models when "patent count" is the dependent variable, as is standard in the literature (see e.g. Hall et al., 1984; Aghion et al., 2013).

The analysed macroeconomic variables are yearly GDP growth and inflation in the supplier's country. ${ }^{8}$ On the demand side, GDP growth may affect our outcome variables, for faster growth presumably increases the demand for all goods, and hence firms' sales and profits. Inflation (measured by the consumer price index) controls for price changes that may affect the real value of our performance indicators (which are in nominal terms), given the long time span covered and the fact that all Orbis and Amadeus data are in current euros and at current exchange rates.

\section{Table 1 - Summary Statistics}

\begin{tabular}{|lcccc|}
\hline & Mean & Std. Dev. & Median & Observations \\
Total Assets ${ }^{9}$ ('000, $€$ ) & 354,229 & $2,353,854$ & 6,842 & 9,670 \\
Intangible Fixed Assets ${ }^{10}$ ('000, €) & 49,619 & 551,680 & 22 & 9,209 \\
Tangible Fixed Assets ${ }^{11}$ ('000, $€$ ) & 68,697 & 671,275 & 719 & 8,740 \\
Number of Employees & 1,333 & 7,459 & 70 & 9,152 \\
Sales ('000, $€$ ) & 306,309 & $1,615,202$ & 10,701 & 7,770 \\
Operating Revenues ('000, €) & 273,064 & $1,495,048$ & 10,942 & 10,092 \\
EBIT ('000, €) & 15,602 & 134,956 & 313 & 8,616 \\
EBIT margin & $4.67 \%$ & 11.58 & $4.25 \%$ & 8,250 \\
Patents & 0.247 & 1.53 & 0 & 25,296 \\
\hline
\end{tabular}

\section{The Empirical Strategy}

\footnotetext{
${ }^{8}$ Source of data: World Bank, http://databank.worldbank.org/data/home.aspx

${ }^{9}$ Orbis/Amadeus definition: "Sum of fixed assets (intangible fixed and tangible fixed) and current assets"

${ }^{10}$ Orbis/Amadeus definition: "All intangible assets such as formation expenses, research expenses, goodwill, development expenses and all other expenses with a long term effect".

${ }^{11}$ Orbis/Amadeus definition: "All tangible assets such as buildings, machinery, etc".
} 
In the last 20 years, the CDM model has been extended and further developed in several directions by many authors. See Lööf et al. (2017) for a review of such development.

The original CDM framework included a structural model where research investment explained innovation output, which in turn affected productivity. The proposed generalisations and extensions concern the nature and the measure of input and outcome variables, the inclusion of additional equations in the model, new estimation methods, different types of data (from cross-sectional to panel), dynamic specifications of the model and different fields of application.

Following the standard CDM framework, Baum et al. (2015) estimated the R\&D-innovationproductivity relationship as a Generalised Structural Equation Model. This approach enables the entire CDM model to be estimated as one system using a full-information maximum likelihood estimator, allowing coefficients to differ across sectors and taking cross-equation error correlation into account. The same type of estimator is employed by Raymond et al. (2015), which integrates dynamics into the $R \& D$-innovation-productivity relationship including lagged values of the dependent variable in each of the equations composing the system. Their results show a causal impact of innovation on productivity and reveal strong persistence in firms' productivity.

One of the most significant developments of the CDM framework, namely Hall and Sena (2017) introduces an initial estimation step to model the firm's decision to invest in innovation and the intensity of such expenditure. They also consider legal protection of intellectual property as a crucial external institution, modeling the relationship between appropriability mechanisms, innovation and firm productivity. Using a sequential 2SLS estimation procedure, they find that innovation, combined with the formal protection methods of intellectual property, tends to deliver the best productivity outcome. From a similar perspective, Van Leeuwen and Mohnen (2017) apply the CDM model to the field of green innovation. Using a structural approach, they investigate relationships linking environmental regulation, eco-investments, eco-innovation and labour productivity. They find a positive and significant impact of environmental regulation on eco-investments and eco-innovations. Resource-saving eco-innovations, in turn, increase productivity.

We test our hypotheses by following two alternative approaches. First, we considered the impact of CERN procurement on each of the outcome variables highlighted in the chain of logical implication described in section 2.4 to investigate the direct effects of procurement. This is done by estimating six different single-equation regression models, which are presented in section 4.1. Then, following the recent literature presented above, we moved to a system of simultaneous equations to better capture the mediated impact of procurement and the complex relations linking it to company economic performance. Specifically, we estimated a four-equations system where the dependent 
variables are: company R\&D effort, the annual number of filed patents, productivity and economic performance. The details of this estimation strategy are discussed in section 4.2.

\subsection{Single-equation regression models}

We compared the values of six different outcome variables for each firm before and after the event, exploiting our time-variant sequence of events. In our setting, this approach represents a version of a difference-in-difference panel (see Angrist and Pishke, 2009, for a methodological discussion, particularly section 5.3 and appendix 5.4), given that we do not have just one before/after year, but twelve such breaks, each involving different firms. In our context, at the beginning of the period (1991), no firm is a CERN supplier for the LHC, and at the end of the period all the sample firms are. In the intervening years, we have a sustained sequence of events (from 1995 to 2008), with the firms' status shift occurring in different years. Hence we were able to use a panel data approach, including (in most years) both treated and non-treated firms, where fixed effects capture unobserved firmspecific heterogeneity that is constant over time and year dummies capture unobserved effects that should affect all firms equally (e.g. business cycle, national and international economic policy, oil shocks). Alternative estimation strategies are discussed later.

In this context, our general approach was to estimate the effect that receiving an order from CERN had, over time, on the firms' outcome variables, controlling for firm characteristics, the macroeconomic situation, and time, country and firm fixed effects. Alternative specifications, with industry rather than firm fixed effects, were also considered. The "CERN effect" is a dummy variable that takes value 0 before the first year the company received an order from CERN and 1 thereafter.

We considered a static panel data model specification in which both performance and firm-level control variables are taken in changes year by year, to avoid spurious regressions (see Granger and Newbold, 1974; Box and Jenkins, 1970).

Specifically, the general empirical model we estimated is:

$\Delta y_{i t}=\beta C E R N_{i t}+\Delta X^{\prime}{ }_{i t} \gamma+\Delta Z^{\prime}{ }_{c t} \theta+\sigma_{s}+\delta_{t}+\rho_{c}+\delta_{t} \rho_{c}+u_{i t}$

where $\Delta y_{i t}$ is the relevant outcome variable (see below) taken in first differences for firm $i$ at time $t$. CERN $N_{i t}$ represents the relevant explanatory variable, the capability to deliver an order to CERN. $\Delta X^{\prime}{ }_{i t}$ is a vector of firm characteristics, mainly reflecting company size, which may influence the firm's ability to capture technology spillovers.

$\Delta Z^{\prime}{ }_{c t}$ is a vector of macroeconomic controls, including $\Delta G D \mathrm{P}_{\mathrm{ct}}$, the yearly percentage change of GDP in the firm's country $c$, and $\Delta C P I_{c t}$, the yearly percentage change in that country's CPI. These variables control for country-level macroeconomic effects due to overall output and price changes. $\delta_{t}$ denotes time-fixed effects, while $\sigma_{s}$ and $\rho_{c}$ are time-invariant unobservable industry- and country- 
specific fixed effects respectively. ${ }^{12}$ Finally, $u_{i t}$ is the random error term, which is clustered by country, allowing for error correlation within the same country.

It is important to note that the resulting estimate of the consequences of procurement is conservative since it evaluates the impact on company outcomes from the year the first order is received, when it is plausible that this impact might be even greater in subsequent years, since some outcomes may take time to change.

Starting from the general specification in equation (1), we estimated four different equations, reflecting the logical chain of events set forth in the conceptual framework (section 2.3): R\&D asset value (2), knowledge production (3), productivity (4) and profitability (5).

The $R \& D$ value equation takes the following specification:

$$
\Delta R \& D_{i t}=\beta C E R N_{i t}+\operatorname{Size}_{i t}^{\prime} \gamma_{1}+\theta_{1} \Delta G D P_{c t}+\theta_{2} \Delta C P I_{c t}+\sigma_{s}+\delta_{t}+\rho_{c}+\delta_{t} \rho_{c}+u_{i t}
$$

where the $\mathrm{R} \& \mathrm{D}$ effort $\left(\triangle R \& D_{i t}\right)$ is proxied by the yearly variation of Intangible Fixed Assets per employee, $\Delta\left(\frac{I A}{e m p l}\right)_{i t}$. For recent examples and a discussion on the matter/equation, see Marin, 2014; Leoncini et al., 2017. Size $e_{i t}$ is a vector including the yearly change in number of employees and either the yearly change in Tangible Fixed Assets (TFA) ${ }^{13}$ or a set of dummy variables for firm size ${ }^{14}$ ranging from a small to very large (reference category).

The second step in the sequence is the estimation of a knowledge production equation:

$$
\Delta \text { Patents }_{i t}=\beta C E R N_{i t}+\operatorname{Size}_{i t}^{\prime} \gamma_{1}+\gamma_{2} \Delta\left(\frac{I A}{T A}\right)_{i t}+\theta_{1} \Delta G D P_{c t}+\sigma_{s}+\delta_{t}+\rho_{c}+u_{i t}
$$

where $\Delta$ Patents $_{i t}$ is the number of patents filed by company $i$ in year $t$. Size $e_{i t}$ is a vector including the yearly change in number of employees and either the change in Total Assets or the set of dummy variables for size in equation (2). In view of the well-documented relationship between R\&D and patents (see e.g. Hall et al., 1984), we control for the variable $\Delta\left(\frac{I A}{T A}\right)_{i t}$, which represents the yearly change in the share of Intangible Assets in Total Assets. Since the dependent variable here is nonmonetary, inflation was dropped from the macroeconomic controls.

The productivity equation takes the form:

$\Delta$ Productivity $_{i t}=\beta C E R N_{i t}+\operatorname{Size}_{i t}^{\prime} \gamma_{1}+\gamma_{2} \Delta R \& D_{i t}+\gamma_{3} \Delta\left(\frac{\text { patents }}{\text { empl }}\right)_{i t}+\theta_{1} \Delta G D P_{c t}+\theta_{2} \Delta C P I_{c t}+\sigma_{s}+\delta_{t}+\rho_{c}+\delta_{t} \rho_{c}+u_{i t}$

\footnotetext{
${ }^{12}$ Clearly, when models are estimated using fixed-effect regressions, vectors $\sigma_{\mathrm{s}}$ and $\rho_{\mathrm{c}}$ are omitted.

${ }^{13}$ Unlike the subsequent equations, this one does not include Total Assets, which by definition includes Intangible Assets, our dependent variable.

${ }^{14}$ These dummy variables are constructed starting from the "size" variable in Orbis, which classifies companies as very large, large, medium and small on the basis of number of employees, total assets and operating revenue.
} 
where the yearly change in sales normalised by the number of employees, $\Delta\left(\frac{\text { sales }}{\text { empl }}\right)_{i t}$, is used as a proxy for labour productivity (see e.g. Raimond et al., 2015). The vector $S_{i z} e_{i t}$ includes the yearly change in number of employees and either the yearly change in Total Assets or the usual set of size dummies.

Finally, as the last link of our chain of implications for testing, we estimated the following performance equation:

$\Delta \operatorname{Performance}_{i t}^{j}=\beta C E R N_{i t}+\operatorname{Size}_{i t}{ }_{i t} \gamma_{1}+\theta_{1} \Delta G D P_{c t}+\theta_{2} \Delta C P I_{c t}+\sigma_{s}+\delta_{t}+\rho_{c}+\delta_{t} \rho_{c}+u_{i t}$

where the superscript $j$ identifies the three different measures of performance that we use: $j=\mathrm{EBIT}$, Operating Revenue and EBIT margin. The vector Size $_{i t}$ considers either the yearly change in Total Assets or the set of size dummies.

In this setting, a pooled OLS regression would result in biased estimates of the vectors of the coefficients, owing to the potential correlation between unobservable, time-invariant firm-specific characteristics and the set of explanatory variables (Cameron Trivedi, 2005). Accordingly, we estimated the models using a fixed-effect (FE) estimator that captures the impact of time-variant variables. The FE estimator enables us to control for time-invariant differences between observations, eliminating potential bias due to the omission of fixed unobserved firm-specific variables such as management quality, corporate governance, reputation, and the like. Moreover, the results of the Hausman Test (reported below) also suggest that, given our data, the FE estimator tends to be the best. Nevertheless, we also ran a robustness check on it by performing RE regressions to control for time-invariant industry characteristics.

A correlation matrix for the variables included in the analysis is available in the Appendix. As expected, larger firm size (in terms of assets and number of employees) is strongly correlated with higher revenues, sales and earnings. However, there appears to be no relevant problem of multicollinearity among the explanatory variables that were used as regressors.

\subsection{System of simultaneous equations}

Until now, we have considered each of the equations underlying the chain of logical implications stretching from the event of becoming a CERN supplier to an increase in company revenues and profitability as single regressions. This was done to better clarify the impact that procurement may have on each of the considered outcome variables. Indeed, this strategy allows the direct impact of procurement on firm innovation outputs, productivity and economic performance to be highlighted.

At this point, we went one step further by estimating our model as a system of simultaneous equations. The standard CDM model was augmented by means of an initial trigger provided by the 
CERN commissioned procurement. This is done by adding the (time-varying) dummy variable "CERN effect" to the R\&D equation. In addition to productivity, earnings and profitability are investigated in the fourth equation of the system.

Since there are endogenous variables on both the left and right sides of each equation, the system was estimated by using a 3SLS procedure (see Zellner and Theil, 1962). Moreover, the 3SLS estimator allows for cross-correlations in the residuals of the equations in the system and is thus more efficient than 2SLS (see Cameron and Trivedi, 2005).

Unlike the single-equation approach, this strategy allows better appraisal of the mediated effect of CERN procurement and so more precisely highlights the complex linkage between procurement and economic performance.

Specifically, the system of equations we estimated is the following:

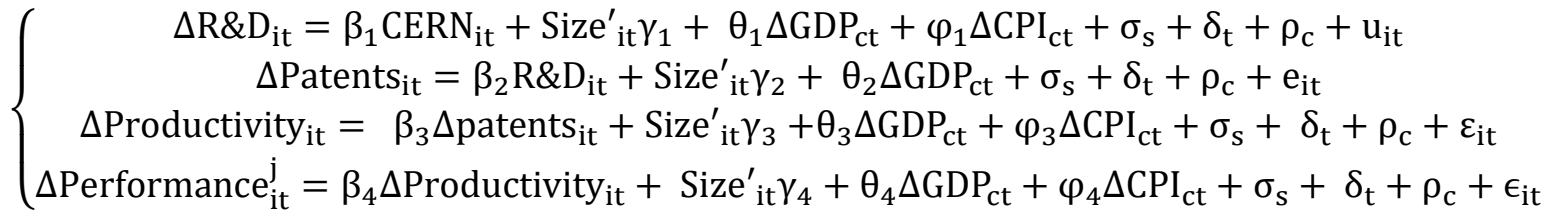

where the variable "Patent" is linearised using the transformation $\ln (1+$ patents $)$, thus allowing the "knowledge production" equation to be estimated in the framework of a linear system.

\section{The Results}

\subsection{The CERN effect on $R \& D$ and knowledge production}

Tables 2 and 3 report the coefficient estimates of the parameters in equations (2) and (3).

The results for equation (2) suggest that after becoming CERN suppliers companies increased their intangible investment. This is consistent with the hypothesis that technological procurement boosts R\&D expenditure. We are aware that intangible fixed assets are an imperfect measure of $R \& D$ spending, but Orbis and Amadeus provide no R\&D data for more than $90 \%$ of the firms, while they include R\&D asset value in intangible fixed assets. Moreover, as we shall see below, the case for this proxy is further supported by the fact that this link is only found for suppliers of high tech-orders (we present the results in section 5.3). Table 2 suggests that our results are robust to alternative specifications, which include different size controls and time-varying fixed effects. ${ }^{16}$

\footnotetext{
${ }^{15}$ Taking log-transformations of patent count is a common practice in the literature investigating the determinants of patenting: see for example Zhao et al. (2017), Li (2012) and Aghion et. al (2013).

${ }^{16}$ In the following tables, we only report the most complete specification where both year and year*country fixed effects are included.
} 
Since Intangible Fixed Assets is normalised by number of employees, the coefficient of their yearly change ( $\Delta$ Employees) estimates the deviation from constant returns to firm size (see Crépon et al. 1998).

Table 2 - Impact of CERN procurement on R\&D effort (proxied by $\Delta$ Intangible Assets/employees)

\begin{tabular}{lcccc}
\hline & $(1)$ & $(2)$ & $(3)$ & $(4)$ \\
& $\Delta \mathrm{R} \& \mathrm{D}$ & $\Delta \mathrm{R} \& \mathrm{D}$ & $\Delta \mathrm{R} \& \mathrm{D}$ & $\Delta \mathrm{R} \& \mathrm{D}$ \\
\hline CERN & $0.925^{* *}$ & $1.164^{* * *}$ & $1.254^{* * *}$ & $0.425^{* * *}$ \\
& $(0.332)$ & $(0.257)$ & $(0.249)$ & $(0.115)$ \\
$\Delta$ Employees (mln) & $-1.99^{* * *}$ & $-1.99^{* * *}$ & $-2.00^{* * *}$ & -0.0341 \\
& $(0.107)$ & $(0.111)$ & $(0.107)$ & $(0.0427)$ \\
$\Delta$ TFA/Employees (mln) & & & & 0.0206 \\
& & & & $(0.0395)$ \\
size_very_large & 0.0868 & 0.290 & 0.492 & \\
size_large & $(0.850)$ & $(0.889)$ & $(1.006)$ & \\
& -0.429 & -0.329 & -0.181 & \\
size_medium & $(0.641)$ & $(0.581)$ & $(0.548)$ & \\
& -0.242 & -0.239 & -0.193 & \\
Macro controls & $(0.598)$ & $(0.558)$ & $(0.526)$ & \\
Years & & & & \\
Years*Country & Yes & Yes & Yes & Yes \\
& No & Yes & Yes & Yes \\
Cons & No & No & Yes & Yes \\
& & & & \\
$\mathrm{R}^{2}$ & -0.246 & -0.377 & -0.350 & -0.522 \\
$\mathrm{~N}$ & $(0.540)$ & $(0.857)$ & $(0.576)$ & $(0.447)$ \\
\hline
\end{tabular}

FE regressions

Standard errors clustered by country in parentheses; $* p<0.10, * * p<0.05, * * * p<0.01$

The positive effect of CERN procurement also emerges in the yearly change in filed patents, which increases after the beginning of the procurement relationship (Table 3). The current ratio of intangible to total assets has a positive and highly significant coefficient, whereas with a one-year lag the ratio is significant in only one of our two specifications; this suggests that the increase in intangible assets reported in Table 2 contributes to innovation capacity.

Interestingly, the coefficient of the CERN effect remains positive and significant at the $1 \%$ level even with these additional controls, meaning that the benefits of procurement presumably go beyond the direct impact of increased $R \& D$ activity. This suggests that technological spillovers may well constitute a positive externality. Part of the R\&D cost of developing a new product commissioned by CERN is of course defrayed by CERN itself, but CERN does not patent the inventions, allowing the supplier to do so and thus to exploit the new process/product developed in the course of the collaboration.

The specifications in columns (7) and (8) include firm fixed effects among the explanatory variables, using the "pre-sample mean scaling" method of Blundell et al. (1999). Thanks to Patstat's long data 
series on companies' patenting behaviour, we were able to compute the pre-sample average of patents, which should reflect the "entry level innovation knowledge stock" (Blundell et al., 1999, p. 534), i.e. the stock of past innovations available to each company at the beginning of our period in 1991, which can serve as an initial condition to control for unobserved heterogeneity.

Table 3 - Impact of CERN procurement on innovation output (proxied by patents)

\begin{tabular}{|c|c|c|c|c|c|c|c|c|}
\hline & $\begin{array}{c}(1) \\
\Delta \text { Patents }\end{array}$ & $\begin{array}{c}(2) \\
\Delta \text { Patents }\end{array}$ & $\begin{array}{c}(3) \\
\Delta \text { Patents }\end{array}$ & $\begin{array}{c}(4) \\
\Delta \text { Patents }\end{array}$ & $\begin{array}{c}(5) \\
\Delta \text { Patents }\end{array}$ & $\begin{array}{c}(6) \\
\Delta \text { Patents }\end{array}$ & $\begin{array}{c}(7) \\
\Delta \text { Patents }\end{array}$ & $\begin{array}{c}(8) \\
\Delta \text { Patents }\end{array}$ \\
\hline CERN & $\begin{array}{l}0.372 * \\
(0.209)\end{array}$ & $\begin{array}{c}0.558 * * * \\
(0.216)\end{array}$ & $\begin{array}{c}0.543 * * * \\
(0.211)\end{array}$ & $\begin{array}{c}0.794 * * * \\
(0.196)\end{array}$ & $\begin{array}{c}0.565 * * * \\
(0.217)\end{array}$ & $\begin{array}{c}0.790 * * * \\
(0.220)\end{array}$ & $\begin{array}{c}0.558 * * * \\
(0.207)\end{array}$ & $\begin{array}{c}0.802 * * * \\
(0.194)\end{array}$ \\
\hline$\Delta$ Employees (mln) & $\begin{array}{l}-0.0181 \\
(0.0158)\end{array}$ & $\begin{array}{l}-0.0533 \\
(0.0384)\end{array}$ & $\begin{array}{l}-0.0152 \\
(0.0163)\end{array}$ & $\begin{array}{l}-0.0547 \\
(0.0394)\end{array}$ & $\begin{array}{l}-0.0140 \\
(0.0157)\end{array}$ & $\begin{array}{l}-0.0486 \\
(0.0386)\end{array}$ & $\begin{array}{l}-0.0151 \\
(0.0163)\end{array}$ & $\begin{array}{l}-0.0547 \\
(0.0395)\end{array}$ \\
\hline$\Delta$ Total Assets (bln) & & $\begin{array}{c}0.123 \\
(0.107)\end{array}$ & & $\begin{array}{c}0.145 \\
(0.113)\end{array}$ & & $\begin{array}{c}0.121 \\
(0.113)\end{array}$ & & $\begin{array}{c}0.145 \\
(0.113)\end{array}$ \\
\hline size_very_large & $\begin{array}{c}4.373 * * * \\
(1.013)\end{array}$ & & $\begin{array}{c}4.170 * * * \\
(1.018)\end{array}$ & & $\begin{array}{c}4.069 * * * \\
(1.032)\end{array}$ & & $\begin{array}{c}4.168 * * * \\
(1.017)\end{array}$ & \\
\hline size_large & $\begin{array}{c}2.908 * * * \\
(1.013)\end{array}$ & & $\begin{array}{c}2.738 * * * \\
(1.018)\end{array}$ & & $\begin{array}{c}2.589 * * \\
(1.033)\end{array}$ & & $\begin{array}{c}2.721 * * * \\
(1.018)\end{array}$ & \\
\hline size_medium & $\begin{array}{c}1.411 \\
(1.018)\end{array}$ & & $\begin{array}{c}1.272 \\
(1.024)\end{array}$ & & $\begin{array}{c}1.061 \\
(1.038)\end{array}$ & & $\begin{array}{c}1.273 \\
(1.023)\end{array}$ & \\
\hline$\Delta(\mathrm{IA} / \mathrm{TA})$ & & & $\begin{array}{c}2.188 * * \\
(0.953)\end{array}$ & $\begin{array}{c}3.685 * * * \\
(1.047)\end{array}$ & & & $\begin{array}{c}2.198 * * \\
(0.959)\end{array}$ & $\begin{array}{c}3.698 * * * * \\
(1.050)\end{array}$ \\
\hline$\Delta(\mathrm{IA} / \mathrm{TA}) \_l a g 1$ & & & & & $\begin{array}{c}0.354 \\
(0.937)\end{array}$ & $\begin{array}{l}1.813^{*} \\
(1.045)\end{array}$ & & \\
\hline GDP_growth & $\begin{array}{c}0.0197 \\
(0.0453)\end{array}$ & $\begin{array}{c}0.0289 \\
(0.0505)\end{array}$ & $\begin{array}{c}0.0612 \\
(0.0485)\end{array}$ & $\begin{array}{l}0.0908 * \\
(0.0533)\end{array}$ & $\begin{array}{c}0.0651 \\
(0.0507)\end{array}$ & $\begin{array}{l}0.0980 * \\
(0.0553)\end{array}$ & $\begin{array}{c}0.0604 \\
(0.0487)\end{array}$ & $\begin{array}{l}0.0904 * \\
(0.0534)\end{array}$ \\
\hline Sector & Yes & Yes & Yes & Yes & Yes & Yes & Yes & Yes \\
\hline Country & Yes & Yes & Yes & Yes & Yes & Yes & Yes & Yes \\
\hline Years & Yes & Yes & Yes & Yes & Yes & Yes & Yes & Yes \\
\hline Firm fixed effects & No & No & No & No & No & No & Yes & Yes \\
\hline Cons & $\begin{array}{c}-3.938 * * * \\
(1.423)\end{array}$ & $\begin{array}{c}-0.722 \\
(1.240) \\
\end{array}$ & $\begin{array}{c}-3.782 * * * \\
(1.373)\end{array}$ & $\begin{array}{c}-0.890 \\
(1.275) \\
\end{array}$ & $\begin{array}{l}-20.52 \\
(14.78) \\
\end{array}$ & $\begin{array}{l}-18.34 \\
(12.40) \\
\end{array}$ & $\begin{array}{c}-3.773 * * * \\
(1.371)\end{array}$ & $\begin{array}{c}-0.889 \\
(1.275)\end{array}$ \\
\hline$N$ & 5278 & 5278 & 4660 & 4660 & 4326 & 4325 & 4660 & 4660 \\
\hline
\end{tabular}

Negative Binomial regressions

Column (6): fixed effects controls using the Blundell et al. (1999) pre-sample mean scaling estimator.

Standard errors clustered by country in parentheses; $* p<0.10$, ** $p<0.05$, *** $p<0.01$

\subsection{CERN effect on performance: productivity, revenue and profitability}

As regards Equation 4, the Orbis/Amadeus data are unfortunately insufficient to estimate changes in total factor productivity by any of the usual econometric methods, which would shrink our sample drastically. However, a positive correlation emerges between LHC procurement and firms' labour productivity, a productivity gauge commonly used in the literature (see e.g. Raimond et al., 2015). As Table 4 shows, this result is robust to alternative specifications. As expected, the coefficients of Intangible Assets and number of patents are positive and statistically significant, but even when they 
are included in the regression, the beneficial impact of procurement persists.

Table 4 - Impact of CERN procurement on productivity (proxied by $\Delta$ sales/employees)

\begin{tabular}{|c|c|c|c|c|c|c|}
\hline & $\begin{array}{c}(1) \\
\Delta \text { Productivity }\end{array}$ & $\begin{array}{c}(2) \\
\Delta \text { Productivity }\end{array}$ & $\begin{array}{c}(3) \\
\Delta \text { Productivity }\end{array}$ & $\begin{array}{c}(4) \\
\Delta \text { Productivity }\end{array}$ & $\begin{array}{c}5) \\
\Delta \text { Productivity }\end{array}$ & $\begin{array}{c}(6) \\
\Delta \text { Productivity }\end{array}$ \\
\hline CERN & $\begin{array}{l}13.65^{* *} \\
(6.671)\end{array}$ & $\begin{array}{l}12.61^{*} \\
(6.597)\end{array}$ & $\begin{array}{l}12.47 * * \\
(4.299)\end{array}$ & $\begin{array}{c}12.05 * * \\
(4.698)\end{array}$ & $\begin{array}{c}12.34 * * * \\
(4.334)\end{array}$ & $\begin{array}{l}11.92 * * \\
(4.687)\end{array}$ \\
\hline$\Delta$ Employees $(\mathrm{mln})$ & $\begin{array}{c}-20.67 * * * \\
(1.367)\end{array}$ & $\begin{array}{c}-19.97 * * * \\
(0.728)\end{array}$ & $\begin{array}{c}-18.29 * * * \\
(0.884)\end{array}$ & $\begin{array}{c}-18.18 * * * \\
(1.257)\end{array}$ & $\begin{array}{c}-18.31 * * * \\
(0.884)\end{array}$ & $\begin{array}{c}-18.19 * * * \\
(1.262)\end{array}$ \\
\hline$\Delta$ Total Assets (bln) & $\begin{array}{c}8.153 \\
(14.95)\end{array}$ & & $\begin{array}{c}1.064 \\
(13.48)\end{array}$ & & $\begin{array}{c}1.082 \\
(13.50)\end{array}$ & \\
\hline size_very_large & & $\begin{array}{c}112.1 \\
(78.53)\end{array}$ & & $\begin{array}{c}135.6 \\
(89.96)\end{array}$ & & $\begin{array}{c}135.7 \\
(90.02)\end{array}$ \\
\hline size_large & & $\begin{array}{c}82.54 \\
(60.94)\end{array}$ & & $\begin{array}{c}103.1 \\
(67.95)\end{array}$ & & $\begin{array}{c}103.1 \\
(68.00)\end{array}$ \\
\hline size_medium & & $\begin{array}{l}-3.868 \\
(15.67)\end{array}$ & & $\begin{array}{c}3.237 \\
(19.09)\end{array}$ & & $\begin{array}{c}3.249 \\
(19.06)\end{array}$ \\
\hline$\Delta \mathrm{R} \& \mathrm{D}$ & & & $\begin{array}{c}0.750 * * \\
(0.329)\end{array}$ & $\begin{array}{l}0.761^{*} \\
(0.363)\end{array}$ & $\begin{array}{c}0.745 * * \\
(0.331)\end{array}$ & $\begin{array}{l}0.756^{*} \\
(0.366)\end{array}$ \\
\hline$\Delta($ Patents/Empl $)$ & & & & & $\begin{array}{l}74.27 * * \\
(32.03)\end{array}$ & $\begin{array}{l}76.00 * * \\
(27.88)\end{array}$ \\
\hline Macro controls & Yes & Yes & Yes & Yes & Yes & Yes \\
\hline Years & Yes & Yes & Yes & Yes & Yes & Yes \\
\hline Years*country & Yes & Yes & Yes & Yes & Yes & Yes \\
\hline Cons & $\begin{array}{c}14.65 * * * \\
(2.120)\end{array}$ & $\begin{array}{l}-53.41 \\
(33.73)\end{array}$ & $\begin{array}{c}10.01 * * * \\
(1.148)\end{array}$ & $\begin{array}{l}-59.09 \\
(35.07)\end{array}$ & $\begin{array}{c}11.66 * * * \\
(1.095)\end{array}$ & $\begin{array}{l}-57.94 \\
(34.89)\end{array}$ \\
\hline $\mathrm{R}^{2}$ & 0.284 & 0.294 & 0.327 & 0.317 & 0.326 & 0.322 \\
\hline$N$ & 3659 & 3659 & 3328 & 3328 & 3320 & 3320 \\
\hline
\end{tabular}

FE regressions

Standard errors clustered by country in parentheses; $* p<0.10, * * p<0.05, * * * p<0.01$

The final link in our chain of implications is the relationship between procurement and firms' revenue and profitability (Equation 5). The estimation results suggest that LHC procurement has a positive and highly significant impact on the change in revenue, EBIT and EBIT margin (Table 5). As is demonstrated in the following section, this result is mainly driven by high-tech suppliers whose CERN effect coefficient is always strongly significant for all performance variables, whereas for nonhigh-tech providers it is often not significant.

If Intangible Assets and patent filings are included in the regression, their coefficients are not statistically significant, ${ }^{17}$ while the CERN effect is practically unaffected in both magnitude and significance.

Table 5 - Impact of CERN procurement on economic outcomes: Revenue, EBIT and EBIT margin

\footnotetext{
${ }^{17}$ This result holds whether the two variables are included jointly or separately.
} 


\begin{tabular}{|c|c|c|c|c|c|c|}
\hline & $\begin{array}{c}(1) \\
\Delta \mathrm{OR}\end{array}$ & $\begin{array}{c}(2) \\
\Delta \mathrm{OR} \\
\end{array}$ & $\begin{array}{c}(3) \\
\Delta \text { EBIT }\end{array}$ & $\begin{array}{c}(4) \\
\Delta \mathrm{EBIT} \\
\end{array}$ & $\begin{array}{c}(5) \\
\Delta \mathrm{EBITm} \\
\end{array}$ & $\begin{array}{c}(6) \\
\Delta \text { EBITm }\end{array}$ \\
\hline CERN & $\begin{array}{c}31139.1 * * * \\
(7867.5)\end{array}$ & $\begin{array}{c}45596.1 * * \\
(18373.5)\end{array}$ & $\begin{array}{c}4942.5 * * \\
(2500.5)\end{array}$ & $\begin{array}{l}5999.5 * * \\
(2365.0)\end{array}$ & $\begin{array}{c}0.854 * * * \\
(0.326)\end{array}$ & $\begin{array}{c}0.838 * * * \\
(0.325)\end{array}$ \\
\hline$\Delta$ Total Assets (bln) & $\begin{array}{c}340457.8 * * * \\
(15386.7)\end{array}$ & & $\begin{array}{c}25239.0 * * * \\
(4747.9)\end{array}$ & & $\begin{array}{l}-0.175 \\
(0.353)\end{array}$ & \\
\hline size_very_large & & $\begin{array}{c}8655.2 * * * \\
(1945.6)\end{array}$ & & $\begin{array}{c}295.0 \\
(455.9)\end{array}$ & & $\begin{array}{c}1.678 \\
(1.529)\end{array}$ \\
\hline size_large & & $\begin{array}{c}-867.1 \\
(2750.6)\end{array}$ & & $\begin{array}{c}1440.6 \\
(1099.6)\end{array}$ & & $\begin{array}{c}1.777 \\
(1.423)\end{array}$ \\
\hline size_medium & & $\begin{array}{l}-1022.1 \\
(1795.0)\end{array}$ & & $\begin{array}{c}77.91 \\
(431.2)\end{array}$ & & $\begin{array}{l}1.780 \\
(1.467)\end{array}$ \\
\hline Macroeconomic controls & Yes & Yes & Yes & Yes & Yes & Yes \\
\hline Years & Yes & Yes & Yes & Yes & Yes & Yes \\
\hline Years*country & Yes & Yes & Yes & Yes & Yes & Yes \\
\hline Cons & $\begin{array}{c}-32100.1 * * * \\
(789.1)\end{array}$ & $\begin{array}{c}-30830.7 * * * \\
(2621.4)\end{array}$ & $\begin{array}{c}-2017.2 * * * \\
(92.84)\end{array}$ & $\begin{array}{c}-2531.8 * * * \\
(359.4)\end{array}$ & $\begin{array}{c}-0.961 * * * \\
(0.0143)\end{array}$ & $\begin{array}{c}-3.313 * * \\
(1.456)\end{array}$ \\
\hline $\mathrm{R}^{2}$ & 0.491 & 0.085 & 0.133 & 0.114 & 0.012 & 0.011 \\
\hline$N$ & 5799 & 5799 & 5812 & 5812 & 5771 & 5771 \\
\hline
\end{tabular}

FE regressions

Standard errors clustered by country in parentheses; $* p<0.10, * * p<0.05, * * * p<0.01$

\subsection{High-tech vs. non-high-tech suppliers}

To determine whether the technological features of procurement influence company performance, we split our sample between high-tech and other suppliers, analysing each subgroup separately.

In order to assign suppliers to one group or the other, we took advantage of the fact that in the original database CERN orders are classified by an "activity code" identifying each product type with a highly detailed 3-digit level. We used the 2-digit classification, which covers around 100 items and was sufficiently detailed for our purposes. In some cases, we also inspected the 3-digit classification to better interpret the technological content.

After a preliminary analysis of the overall distribution of order codes, we followed Florio et al. (2016) in identifying the specific activity codes most likely to be associated with high-tech goods and services for the construction of the LHC. In some instances the code descriptors were generic ("28Electrical engineering," say, or "45-Software"). To minimise classification errors, we sampled 300 orders for a more in-depth analysis. These orders were placed with 207 different suppliers, $16 \%$ of all those who received at least one order for the LHC during the period under analysis. The orders thus sampled were then evaluated in detail by CERN experts and classified, according to their technological intensity, along a five-point scale designed to capture differences in both product specificity and closeness of the supplier's collaboration with CERN:

Class 1: most likely "off-the-shelf” orders of low technological intensity;

Class 2: off-the-shelf orders with average technological intensity;

Class 3: mostly off-the-shelf but usually high-tech and requiring some careful specification; 
Class 4: high-tech orders with moderate to high intensity of specification activity to customise products for the LHC;

Class 5: products at the technological frontier, with intensive customisation and co-design involving CERN staff.

We defined high-tech codes as Classes 3, 4 and 5 and then divided the LHC suppliers into two broad groups, according to their opportunity to deliver high-tech orders in the initial procurement event. According to the activity code assigned to the first order, $63 \%$ of our sample companies are part of the high-tech category, with a very slight over-representation of around 2 percentage points in relation to the original CERN data (61\%). There is some risk of misclassification, in that non-hightech companies may have gained the ability, over time, to satisfy high-tech orders, and that many companies received more than one order, which are not necessarily all coded alike. However, the data indicate that the first order is generally a good predictor of the technological intensity of subsequent ones.

As noted earlier, longer term profits and profit margins respond to procurement only for hightech suppliers, which seems to confirm that the determinants of the benefits generated by LHC procurement include specific learning spillovers and innovation (see Table 6). For operating revenue, however, the difference between the two groups is more nuanced. By applying a stricter definition of high-tech orders (see section 6.3), the results for all performance variables are qualitatively confirmed.

Equations (2), (3) and (4) have also been estimated separately for high-tech and non-high-tech suppliers. The main results are briefly reported here. Equation (2) indicates that the increase in Intangible Assets after the procurement relationship is established occurs at high-tech companies only. The correlation between LHC procurement and number of patents (Equation 3) is positive and statistically significant in both groups. Finally, as regards productivity (Equation 4), while a positive and significant correlation between the CERN effect and sales per employee is obtained, when the two subsamples are regressed separately the correlation is no longer significant, probably owing to the considerable reduction in sample size.

Table 6-Revenues and Profitability: High tech vs. non high-tech companies

\begin{tabular}{lcccccc}
\hline & HT & NHT & HT & NHT & HT & NHT \\
& $(1)$ & $(2)$ & $(3)$ & $(4)$ & (5) & (6) \\
& $\Delta$ OR & $\Delta$ OR & $\Delta$ EBIT & $\Delta$ EBIT & $\Delta$ EBITm & $\Delta$ EBITm \\
\hline CERN & $36974.5^{* * *}$ & $16512.8^{* *}$ & $8631.3^{* *}$ & -2034.0 & $0.552^{* *}$ & 1.339 \\
& $(7926.7)$ & $(6839.0)$ & $(3766.0)$ & $(2841.5)$ & $(0.241)$ & $(0.995)$ \\
$\Delta$ Total Assets (bln) & $330974.6^{* * *}$ & $962831.1^{*}$ & $23722.3^{* * *}$ & $98216.5 * * *$ & -0.233 & 1.862 \\
& $(16063.6)$ & $(465746.7)$ & $(4588.8)$ & $(5953.9)$ & $(0.390)$ & $(2.110)$ \\
Macro controls & Yes & Yes & Yes & Yes & Yes & Yes
\end{tabular}




\begin{tabular}{lcccccc} 
Years & Yes & Yes & Yes & Yes & Yes & Yes \\
Years*country & Yes & Yes & Yes & Yes & Yes & Yes \\
& & & & & & \\
Cons & -41.82 & -36200.6 & $-1695.0^{* * *}$ & $7511.4 * * *$ & $0.0562 * * *$ & $5.105^{* * *}$ \\
& $(387.6)$ & $(27493.2)$ & $(156.7)$ & $(1298.2)$ & $(0.00984)$ & $(0.313)$ \\
$\mathrm{R}^{2}$ & 0.017 & 0.019 & 0.581 & 0.511 & 0.131 & 0.276 \\
\hline$N$ & 3703 & 2096 & 3706 & 2106 & 3687 & 2084 \\
\hline
\end{tabular}

FE regressions

Standard errors clustered by country in parentheses; $* p<0.10, * * p<0.05, * * * p<0.01$

\subsection{Estimating the model as a system of simultaneous equations}

The present section illustrates the results that were obtained when our model was estimated as a system of simultaneous equations. The findings are consistent with those previously obtained from the single-regressions estimation, pointing out to the role of procurement in triggering the logical chain of implications that we aimed to test (Tables 7-9). Specifically, the coefficients obtained from the estimation of the system (6) highlight the direct "CERN effect" on R\&D investments as well as its mediated impact on company innovation output, productivity and economic performance.

It is important to note that the reduction in sample size with respect to the single-equation estimation is due to the fact that we are now considering all four outcome variables simultaneously, so the total number of missing observations increases (see footnote 6 , section 3 ).

For high-tech companies, the estimates clearly show that the impact of procurement on innovativeness comes by way of $\mathrm{R} \& \mathrm{D}$, which in turn affects productivity, whose rise finally enhances the economic outcomes.

For non-high-tech companies, by contrast, there is no positive influence of procurement on R\&D and innovation output, suggesting that the significant association of productivity with revenues and profits that shows up in the final estimation stage is not driven by technological spill-overs that boost technical know-how, but instead by such factors as market penetration and reputational gains.

Table 7 - 3SLS estimation of the model in which the economic performance gauge is revenues

\begin{tabular}{lccc}
\hline & (1) & $(2)$ & NON-HIGH-TECH \\
\hline$\Delta$ RULD & & HIGH-TECH & \\
& & & -0.258 \\
CERN & $0.675^{* * *}$ & $1.276^{* * *}$ & $(0.387)$ \\
& $(0.050)$ & $(0.129)$ & -0.125 \\
$\Delta$ Employees (mln) & -0.0788 & -0.0372 & $(0.111)$ \\
$\Delta$ Tangible Assets (bln) & $(0.067)$ & $-1.698^{* * *}$ & 8.680 \\
& $-6.035^{* * *}$ & $(0.312)$ & $(12.270)$ \\
Macroeconomic controls & $(0.484)$ & & Yes \\
Country FE & Yes & Yes & Yes \\
Time FE & Yes & Yes & Yes \\
Sector FE & Yes & Yes & Yes \\
Cons & Yes & $-25.79^{* * *}$ & -1.158 \\
& -1.544 & $(4.090)$ & $(5.639)$
\end{tabular}




\begin{tabular}{|c|c|c|c|}
\hline \multicolumn{4}{|l|}{$\Delta$ Patents } \\
\hline$\Delta \mathrm{R} \& \mathrm{D}$ & $\begin{array}{c}7.532 * * * \\
(0.462)\end{array}$ & $\begin{array}{c}4.006 * * * \\
(0.330)\end{array}$ & $\begin{array}{c}-0.109 * * * \\
(0.035)\end{array}$ \\
\hline$\Delta$ Employees (mln) & $\begin{array}{c}1.185^{* * *} * \\
(0.099)\end{array}$ & $\begin{array}{c}0.685 * * * \\
(0.086)\end{array}$ & $\begin{array}{c}-0.0163^{*} \\
(0.009)\end{array}$ \\
\hline$\Delta$ Total Assets (bln) & $\begin{array}{c}-4.347 * * * \\
(0.308)\end{array}$ & $\begin{array}{c}-2.203 * * * \\
(0.221)\end{array}$ & $\begin{array}{c}0.513 * * * \\
(0.141)\end{array}$ \\
\hline Macroeconomics controls & Yes & Yes & Yes \\
\hline Country FE & Yes & Yes & Yes \\
\hline Time FE & Yes & Yes & Yes \\
\hline Sector FE & Yes & Yes & Yes \\
\hline Cons & $\begin{array}{c}9.256 * * * \\
(3.467)\end{array}$ & $\begin{array}{c}105.0 * * * \\
(9.057)\end{array}$ & $\begin{array}{l}-0.400 \\
(0.372)\end{array}$ \\
\hline \multicolumn{4}{|l|}{$\Delta$ Productivity } \\
\hline$\Delta$ Patents & $\begin{array}{c}2881.1 * * * \\
(732.3)\end{array}$ & $\begin{array}{c}2550.3 * * * \\
(731.4)\end{array}$ & $\begin{array}{c}2866.6^{* * * *} \\
(440.0)\end{array}$ \\
\hline$\Delta$ Employees (mln) & $\begin{array}{c}-0.0482 * * * * \\
(0.0133)\end{array}$ & $\begin{array}{c}-0.0356^{* * * *} \\
(0.0117)\end{array}$ & $\begin{array}{c}-0.0511^{*} * * * \\
(0.0128)\end{array}$ \\
\hline$\Delta$ Total Assets (bln) & $\begin{array}{l}-20.57 \\
(42.31)\end{array}$ & $\begin{array}{l}-24.38 \\
(42.36)\end{array}$ & $\begin{array}{l}-118.7 \\
(117.9)\end{array}$ \\
\hline Macroeconomic controls & Yes & Yes & Yes \\
\hline Country FE & Yes & Yes & Yes \\
\hline Time FE & Yes & Yes & Yes \\
\hline Sector FE & Yes & Yes & Yes \\
\hline Cons & $\begin{array}{c}63.54 \\
(638.6) \\
\end{array}$ & $\begin{array}{r}-250.3 \\
(803.4) \\
\end{array}$ & $\begin{array}{c}835.5 * * \\
(369.1) \\
\end{array}$ \\
\hline \multicolumn{4}{|l|}{$\Delta$ Revenues } \\
\hline$\Delta$ Productivity & $\begin{array}{c}348.3 * * * \\
(42.28)\end{array}$ & $\begin{array}{c}392.7 * * * \\
(43.51)\end{array}$ & $\begin{array}{c}3640.0 * * * \\
(816.5)\end{array}$ \\
\hline$\Delta$ Employees (mln) & $\begin{array}{c}69999.1 * * * \\
(2337.6)\end{array}$ & $\begin{array}{c}101865.1 * * * \\
(3877.3)\end{array}$ & $\begin{array}{c}136178.2 * * * * \\
(22295.2)\end{array}$ \\
\hline$\Delta$ Total Assets (mln) & $\begin{array}{c}226.306^{* * * *} \\
(7.676)\end{array}$ & $\begin{array}{c}167.882 * * * * \\
(9.360)\end{array}$ & $\begin{array}{c}292.450^{* *} \\
(131.453)\end{array}$ \\
\hline Macroeconomics controls & Yes & Yes & Yes \\
\hline Country FE & Yes & Yes & Yes \\
\hline Time FE & Yes & Yes & Yes \\
\hline Sector FE & Yes & Yes & Yes \\
\hline Cons & $\begin{array}{c}-39025.0 \\
(101588.8)\end{array}$ & $\begin{array}{c}-64861.4 \\
(139192.6)\end{array}$ & $\begin{array}{c}-96391.0 \\
(261069.1)\end{array}$ \\
\hline 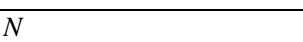 & 2850 & 1876 & 974 \\
\hline
\end{tabular}

Table 8-3SLS estimation of the model in which the economic performance gauge is EBIT

\begin{tabular}{lccc}
\hline & $(1)$ & $(2)$ & $(3)$ \\
& FULL SAMPLE & HIGH-TECH & \\
\hline$\Delta$ R\&D & & & -0.250 \\
& & & $(0.398)$ \\
CERN & $0.668^{* * *}$ & $\left(.256^{* * *}\right.$ & -0.125 \\
& $(0.050)$ & $-0.129)$ & $(0.111)$ \\
$\Delta$ Employees (mln) & -0.0787 & $(0.0870$ & 11.23 \\
$\Delta$ Tangible Assets (bln) & $(0.067)$ & $-1.664 * * *$ & $(12.37)$ \\
& $-5.950^{* * *}$ & $(0.312)$ & Yes \\
Macroeconomic controls & $(0.482)$ & Yes & Yes \\
Country FE & Yes & Yes & Yes \\
Time FE & Yes & Yes & Yes \\
Sector FE & Yes & Yes & -1.089 \\
Cons & -1.540 & $-25.79 * * *$ & $(5.636)$ \\
& $(3.671)$ & $(4.090)$ & $-0.102 * * *$
\end{tabular}




\begin{tabular}{|c|c|c|c|}
\hline & $(0.459)$ & $(0.330)$ & $(0.034)$ \\
\hline$\Delta$ Employees (mln) & $\begin{array}{c}1.171^{* * * *} \\
(0.099)\end{array}$ & $\begin{array}{c}0.675 * * * \\
(0.086)\end{array}$ & $\begin{array}{c}-0.0152^{*} \\
(0.009)\end{array}$ \\
\hline$\Delta$ Total Assets (bln) & $\begin{array}{c}-4.290 * * * \\
(0.306)\end{array}$ & $\begin{array}{c}-2.170 * * * \\
(0.220)\end{array}$ & $\begin{array}{c}0.506 * * * \\
(0.140)\end{array}$ \\
\hline Macroeconomics controls & Yes & Yes & Yes \\
\hline Country FE & Yes & Yes & Yes \\
\hline Time FE & Yes & Yes & Yes \\
\hline Sector FE & Yes & Yes & Yes \\
\hline cons & $\begin{array}{c}9.142^{* * * *} \\
(3.466)\end{array}$ & $\begin{array}{c}103.7 * * * * \\
(9.051)\end{array}$ & $\begin{array}{l}-0.384 \\
(0.362) \\
\end{array}$ \\
\hline \multicolumn{4}{|l|}{$\Delta$ Productivity } \\
\hline$\Delta$ Patents & $\begin{array}{c}2848.6 * * * \\
(731.7)\end{array}$ & $\begin{array}{c}2535.5 * * * \\
(731.2)\end{array}$ & $\begin{array}{c}2815.7 * * * \\
(443.9)\end{array}$ \\
\hline$\Delta$ Employees (mln) & $\begin{array}{c}-0.0491 * * * \\
(0.013)\end{array}$ & $\begin{array}{c}-0.0369 * * * \\
(0.012)\end{array}$ & $\begin{array}{c}-0.0510 * * * \\
(0.013)\end{array}$ \\
\hline$\Delta$ Total Assets (bln) & $\begin{array}{l}-15.52 \\
(42.28)\end{array}$ & $\begin{array}{l}-19.94 \\
(42.35)\end{array}$ & $\begin{array}{l}-113.0 \\
(118.8)\end{array}$ \\
\hline Macroeconomic controls & Yes & Yes & Yes \\
\hline Country FE & Yes & Yes & Yes \\
\hline Time FE & Yes & Yes & Yes \\
\hline Sector FE & Yes & Yes & Yes \\
\hline cons & $\begin{array}{c}57.26 \\
(638.3)\end{array}$ & $\begin{array}{l}-258.1 \\
(803.4)\end{array}$ & $\begin{array}{c}801.7^{* *} \\
(371.3)\end{array}$ \\
\hline \multicolumn{4}{|l|}{$\Delta$ Revenues } \\
\hline$\Delta$ Productivity & $\begin{array}{c}209.6 * * * \\
(25.68)\end{array}$ & $\begin{array}{c}221.2 * * * \\
(30.16)\end{array}$ & $\begin{array}{c}211.7 * * * \\
(73.97)\end{array}$ \\
\hline$\Delta$ Employees (mln) & $\begin{array}{c}8739.2 * * * * \\
(1415.5)\end{array}$ & $\begin{array}{c}16710.0^{* * * *} \\
(2678.4)\end{array}$ & $\begin{array}{c}5434.3 * * * \\
(2015.8)\end{array}$ \\
\hline$\Delta$ Total Assets (mln) & $\begin{array}{c}21310.4 * * * \\
(4663.1)\end{array}$ & $\begin{array}{c}8888.5 \\
(6481.9)\end{array}$ & $\begin{array}{r}62310.0 * * * \\
(11839.7)\end{array}$ \\
\hline Macroeconomics controls & Yes & Yes & Yes \\
\hline Country FE & Yes & Yes & Yes \\
\hline Time FE & Yes & Yes & Yes \\
\hline Sector FE & Yes & Yes & Yes \\
\hline Cons & $\begin{array}{c}-1949.1 \\
(61762.9)\end{array}$ & $\begin{array}{l}-11787.3 \\
(96571.7)\end{array}$ & $\begin{array}{c}-9095.6 \\
(23364.0)\end{array}$ \\
\hline$N$ & 2852 & 1876 & 976 \\
\hline
\end{tabular}

Table 9-3SLS estimation of the model in which the economic performance gauge is EBIT margin

\begin{tabular}{|c|c|c|c|}
\hline & $\begin{array}{c}(1) \\
\text { FULL SAMPLE }\end{array}$ & $\begin{array}{c}(2) \\
\text { HIGH-TECH }\end{array}$ & $\begin{array}{c}\text { (3) } \\
\text { NON-HIGH-TECH }\end{array}$ \\
\hline \multicolumn{4}{|l|}{$\Delta \mathbf{R} \& \mathbf{D}$} \\
\hline CERN & $\begin{array}{c}0.723 * * * \\
(0.053)\end{array}$ & $\begin{array}{l}1.346^{* * * *} \\
(0.138)\end{array}$ & $\begin{array}{l}-0.365 \\
(0.401)\end{array}$ \\
\hline$\Delta$ Employees (mln) & $\begin{array}{l}-0.0788 \\
(0.067)\end{array}$ & $\begin{array}{l}-0.0374 \\
(0.085)\end{array}$ & $\begin{array}{l}-0.124 \\
(0.112)\end{array}$ \\
\hline$\Delta$ Tangible Assets (bln) & $\begin{array}{c}-5.945^{* * *} * \\
(0.477)\end{array}$ & $\begin{array}{c}-1.660 * * * \\
(0.319)\end{array}$ & $\begin{array}{c}9.342 \\
(12.36)\end{array}$ \\
\hline Macroeconomic controls & Yes & Yes & Yes \\
\hline Country FE & Yes & Yes & Yes \\
\hline Time FE & Yes & Yes & Yes \\
\hline Sector FE & Yes & Yes & Yes \\
\hline cons & $\begin{array}{c}-1.588 \\
(3.677) \\
\end{array}$ & $\begin{array}{c}-25.89 * * * \\
(4.094) \\
\end{array}$ & $\begin{array}{l}-1.103 \\
(5.651) \\
\end{array}$ \\
\hline \multicolumn{4}{|l|}{$\Delta$ Patents } \\
\hline$\Delta \mathrm{R} \& \mathrm{D}$ & $\begin{array}{l}7.288 * * * \\
(0.443)\end{array}$ & $\begin{array}{l}3.781 * * * \\
(0.314)\end{array}$ & $\begin{array}{c}-0.107 * * * \\
(0.035)\end{array}$ \\
\hline$\Delta$ Employees (mln) & $\begin{array}{c}1.141 * * * \\
(0.096)\end{array}$ & $\begin{array}{c}0.641 * * * \\
(0.081)\end{array}$ & $\begin{array}{c}-0.0159 * \\
(0.009)\end{array}$ \\
\hline
\end{tabular}




\begin{tabular}{|c|c|c|c|}
\hline$\Delta$ Total Assets (bln) & $\begin{array}{c}-4.191 * * * \\
(0.295)\end{array}$ & $\begin{array}{c}-2.068 * * * \\
(0.209)\end{array}$ & $\begin{array}{c}0.511 * * * \\
(0.141)\end{array}$ \\
\hline $\begin{array}{l}\text { Macroeconomics controls } \\
\text { Country FE } \\
\text { Time FE } \\
\text { Sector FE }\end{array}$ & $\begin{array}{l}\text { Yes } \\
\text { Yes } \\
\text { Yes } \\
\text { Yes }\end{array}$ & $\begin{array}{l}\text { Yes } \\
\text { Yes } \\
\text { Yes } \\
\text { Yes }\end{array}$ & $\begin{array}{l}\text { Yes } \\
\text { Yes } \\
\text { Yes } \\
\text { Yes }\end{array}$ \\
\hline cons & $\begin{array}{c}9.193 * * * \\
(3.399) \\
\end{array}$ & $\begin{array}{c}99.65 * * * \\
(8.651) \\
\end{array}$ & $\begin{array}{l}-0.396 \\
(0.367) \\
\end{array}$ \\
\hline \multicolumn{4}{|l|}{$\Delta$ Productivity } \\
\hline$\Delta$ Patents & $\begin{array}{c}2871.3 * * * \\
(735.2)\end{array}$ & $\begin{array}{c}2515.0 * * * \\
(732.7)\end{array}$ & $\begin{array}{c}2824.3 * * * \\
(434.0)\end{array}$ \\
\hline$\Delta$ Employees (mln) & $\begin{array}{c}-0.0484 * * * \\
(0.013)\end{array}$ & $\begin{array}{c}-0.0354 * * * \\
(0.012)\end{array}$ & $\begin{array}{c}-0.0509 * * * \\
(0.013)\end{array}$ \\
\hline$\Delta$ Total Assets (bln) & $\begin{array}{c}-19.13 \\
(42.45)\end{array}$ & $\begin{array}{c}-22.95 \\
(42.47)\end{array}$ & $\begin{array}{l}-116.2 \\
(116.2)\end{array}$ \\
\hline Macroeconomic controls & Yes & Yes & Yes \\
\hline Country FE & Yes & Yes & Yes \\
\hline Time FE & Yes & Yes & Yes \\
\hline Sector FE & Yes & Yes & Yes \\
\hline cons & $\begin{array}{c}65.24 \\
(640.6) \\
\end{array}$ & $\begin{array}{r}-244.3 \\
(805.4) \\
\end{array}$ & $\begin{array}{c}816.2 * * \\
(364.2) \\
\end{array}$ \\
\hline \multicolumn{4}{|l|}{$\Delta$ Revenues } \\
\hline$\Delta$ Productivity & $\begin{array}{l}0.0027 \\
(0.002)\end{array}$ & $\begin{array}{c}0.0034 * \\
(0.002)\end{array}$ & $\begin{array}{c}-0.0030 \\
(0.016)\end{array}$ \\
\hline$\Delta$ Employees (mln) & $\begin{array}{l}0.0881 \\
(0.099)\end{array}$ & $\begin{array}{c}0.347 * * \\
(0.159)\end{array}$ & $\begin{array}{l}-0.183 \\
(0.445)\end{array}$ \\
\hline$\Delta$ Total Assets (mln) & $\begin{array}{l}-0.270 \\
(0.324)\end{array}$ & $\begin{array}{l}-0.677^{*} \\
(0.382)\end{array}$ & $\begin{array}{c}0.774 \\
(2.614)\end{array}$ \\
\hline Macroeconomics controls & Yes & Yes & Yes \\
\hline Country FE & Yes & Yes & Yes \\
\hline Time FE & Yes & Yes & Yes \\
\hline Sector FE & Yes & Yes & Yes \\
\hline Cons & $\begin{array}{r}-2.430 \\
(4.282) \\
\end{array}$ & $\begin{array}{l}-2.446 \\
(5.685) \\
\end{array}$ & $\begin{array}{c}1.802 \\
(5.124) \\
\end{array}$ \\
\hline$N$ & 2839 & 1869 & 970 \\
\hline
\end{tabular}

\section{Robustness checks}

\subsection{Alternative estimation methods}

Although the Hausman test suggested the use of an FE estimator for most of our regressions ${ }^{18}$, we also estimated equations (2), (4) and (5) using a Random Effect (RE) estimator, to check for robustness to alternative estimation techniques. The latter method also allows the use not only of time-varying but also of time-invariant controls such as industry and country-fixed effects, which may influence firm R\&D investment and economic performance. As regards innovation equation (3), we tested robustness by using Poisson instead of Negative Binomial regression.

For the most part, our results are confirmed in both coefficient magnitude and statistical significance (see Tables A1-A4 in the Appendix). The sole exception is specification (4) of the

\footnotetext{
${ }^{18}$ The Hausman Test always rejects the null (RE consistent and efficient) in revenue and productivity regressions and in most of the specifications of EBIT and EBIT margin regressions. It never rejects the null in knowledge production regressions. As FE is the preferred model in most cases, for more uniformed expositions we first presented the results of all FE regressions and then, as a robustness check, the RE estimates.
} 
knowledge equation (Table A1, Appendix), where if the Tangible Fixed Assets variable (normalised by the number of employees) is used as a size control, the positive coefficient of the CERN effect loses its statistical significance.

We also estimated equations (2), (4) and (5) by simple pooled OLS regressions, with and without firm-fixed effects. The results (not reported here for reasons of space) confirm that after becoming LHC suppliers companies exhibit, on average, increases in intangible assets and gains in both productivity and profitability.

As to the innovation equation (3), Table A2 in the Appendix shows again that the findings are not affected by the estimation method.

\subsection{Dynamics}

For regression models (2)-(4), we also tested dynamic specifications with lagged outcome variables as an additional control. This procedure accounts for possible time trends that might persist even after controlling for macroeconomic variables and is generally advisable when effect persistency may be hypothesised (see e.g. Verbeek, 2012, p. 396). We are aware, however, that in the absence of proper instruments, the inclusion of a lagged dependent variable as a regressor may pose problems of endogeneity due to its correlation with the random error term. Once again, however, the results were qualitatively consistent with those of the static models, with only marginal changes in coefficient magnitudes, suggesting that the shift to dynamic specifications does not give rise to substantial endogeneity issues in our setting. The estimates are reported in Tables A5 and A6 in the Appendix. Past changes in profit margin, EBIT, intangible assets and productivity are inversely and very significantly correlated with their current values, suggesting a smoothing process over time. On the other hand, past changes in revenue and patent filings are positively correlated with their current values, suggesting inertia in firms' revenue and propensity to innovate.

\subsection{Alternative classification of high-tech orders and alternative definition of high-tech suppliers}

To check the robustness of the estimates in Table 6, we applied a stricter standard to classify orders as "high-tech", namely a technology intensity score of at least 4 . Only $22.3 \%$ of the sample is now qualified as "high-tech," but despite this drastic alteration of the proportions of high- and lowtech groups, the results are only marginally affected. LHC procurement is found to have a positive and significant impact on high-tech suppliers' EBIT, revenue and EBIT margin. Coefficient magnitudes are considerably greater than when orders with a technology intensity score of 3 are included. This result can be read as indicating that the more technologically complex the received order is, the higher the return to the supplier. However, as concerns the stricter definition, we also found a significant impact on the revenue of non-high-tech suppliers (perhaps a reputation effect). 
We applied another, more restrictive, classification of companies in the high-tech group: only firms whose high-tech orders make up more than $50 \%$ of their total received orders may be considered high-tech companies. According to this new definition, 58\% of our sample suppliers are classified as high-tech. All of our results are confirmed in magnitude and significance level, both for the entire sample and for the high-tech subsample (the impact on revenue and EBIT is slightly greater, that on EBIT margin smaller). For the non-high-tech group, revenue and EBIT are not affected in a statistically significant way, while the effect on EBIT margin becomes significant at the $10 \%$ level $(\mathrm{p}$-value $=0.052)$.

\section{Discussion and concluding remarks}

There are various reasons why one organisation may need another to supply an input, rather than producing it internally: time constraints, lack of production capacity, lack of know-how, need to master the production process beyond prototyping, uncertainty concerning actual production costs, strategic focus on certain markets, and so on. Therefore, the procurement relationship may or may not create learning opportunities for the supplier. If the customer wants to buy a standard, "off-theshelf" product in relatively limited quantities, the learning opportunity is negligible, as there is no need to design or adopt any new technology. But where the customer requires substantial quality improvement to the supplier's product or a massive increase in quantity, the Arrow-Solow mechanism, as discussed in section 2.1, would lead to a possible learning process, hence increased $\mathrm{R} \& \mathrm{D}$, innovation, productivity and profitability.

A basic research infrastructure project typically requires two sets of tangible assets: those needed for the infrastructure itself - say, a particle accelerator - and those needed to exploit experimental data, such as detectors and information technology. In either case, the entity that manages the research infrastructure may need external firms to supply such assets. After construction, there may still be procurement relationships for operation and maintenance. The literature cited in section 2.3 makes it abundantly clear that procurement by large-scale research infrastructures ("Big Science") can generate learning effects and innovation. The mechanism is similar, but not identical, to that found in high-tech industries such as the production of airframes (see Eliasson 2010, 2011) mentioned by Arrow (1962) and discussed in greater detail by Solow (1997). Some aspects of the discontinuity are closer to Pisano’s “learning-before-doing” concept (1996).

The main specificity here is that in most cases the procurement contract between research infrastructure and supplier involves organisations with different fundamental objectives: profit maximisation, certainly, for the supplier, but not for basic research organisations like CERN, NASA, 
the European Space Agency and several other institutions. While the latter need to be cost-effective, given their budget constraints, their fundamental objective is to maximise knowledge without gaining a profit. Hence the owners of these structures do not have the usual incentive to appropriate the rents from invention and innovation. For example, they tend not to protect their discoveries by patenting, even when this is practicable and would be profitable. As a consequence, in the procurement relationship, these institutions will generally pay a reasonable price to the firm for the input and will usually not seek compensation for any knowledge spillover that may occur. Moreover, as by definition the research institution wants to discover something previously unknown, it is likely that at least a part of the necessary tangible and intangible assets will consist in entirely new products or substantial improvements to existing ones, or else will have to be produced on an unprecedented scale or with enormously greater precision. Thus, in this context, there is a twofold mechanism for positive externality: the nature of the assets required by the research infrastructure and its disinterest in appropriating any rent that may arise from learning. The suppliers, instead, being profit maximisers, will take advantage of the asymmetry of objectives and seek to gain a profit from what they have been able to learn in the longer term.

To test this thesis, we investigated the impact of procurement by means of a very large-scale research infrastructure, CERN's Large Hadron Collider, on the companies involved in the supply chain. Specifically, we wanted to assess whether procurement may enhance economic performance by triggering a chain of events: becoming a CERN supplier increases R\&D effort and innovative capacity, which in turn boosts labour productivity, ultimately increasing revenue and profitability.

We found a positive and statistically significant correlation over time between procurement events and each of the outcome variables we considered, while controlling for observable firm characteristics and macroeconomic conditions, as well as for unobserved time, country, industry and firm-level fixed effects. After becoming suppliers, companies generally experienced a rise in intangible assets per employee (our proxy for R\&D effort) and in annual patent filings (our proxy for innovation). Labour productivity, proxied by sales per employee, also increased, as did revenues, EBIT and EBIT margin. The results are confirmed both by estimating single-equation regression models and a system of simultaneous equations.

These findings are consistent with the qualitative insights of Autio et al. (2003) and Florio et al. (2017). The latter reports the results of the broadest and most recent survey of CERN suppliers. Three types of outcome stem from suppliers' cooperation with CERN: innovation (development of new products, services and technologies), learning (acquisition of technical know-how, improvement in the quality of products and services, changes in production processes) and market penetration (acquisition of new customers and market benefits due to reputational gains). These outcomes 
represent "intermediate outputs" which in turn impact on suppliers' economic performance. Our findings on suppliers' development activities and profits were broadly consistent with those results, but our approach is entirely novel. This is the first attempt to measure the procurement effect of Big Science quantitatively by using publicly available company reports rather than surveys, thus precluding subjective bias of the respondents. Moreover, unlike case studies and surveys, our method is replicable whenever the research infrastructure discloses the identity of its suppliers, the dates in which the orders are made, and the kind of product requested. And as far as we know, our paper offers the first empirical analysis of the effect that procurement by a basic research infrastructure may have on the number of patents filed by suppliers, along the lines of some of the literature on the effects of university research (section 2.2).

Two potentially relevant issues are not dealt with in our study. First of all, we did not look at the survival of supplier firms: some companies may have gone bankrupt during the period considered and were therefore not included in the sample. The same goes for suppliers' attractiveness of entry. Second, the availability of financial information in the Orbis/Amadeus databases determined the size and the composition of our sample, which as a result might not be randomly selected. Since our dataset does not allow taking these issues into account, they have been left for future research.

Our findings indicate the existence of important learning spillovers from large-scale basic research infrastructures to their technology suppliers and suggest that the learning process that is generated by procurement is likely to lead to product and process innovation and ultimately higher profitability for high-tech firms. Generic reputational effects would appear to be less substantial, as there is no - or at best modest in some models - correlation over time between procurement events and non-high-tech suppliers' revenue, profit or profit margin. If the data had indicated an equally significant "CERN effect" for firms involved in non-high-tech procurement, our findings could have been interpreted as reflecting, above all, a generic signaling or reputational effect, thus increasing market opportunities or permitting the firm to charge higher prices. Of course, we cannot rule out reputational effects or other marketing drivers for high-tech firms as well: advertising their capability to handle the demanding requirements of LHC technology could well constitute a persuasive marketing argument. This combination of innovation and reputational effects is, after all, exactly what previous narratives and surveys would have suggested.

These findings carry two implications for science policy. First, it would be helpful if publicly funded institutions that operate research infrastructures made the information on their procurement available for independent inquiry, as CERN did for us. Matching these data with the long-term economic and financial data of the firms in the supply chain and with their patent filings would appear to be both feasible and fruitful. 
Second, governments and funding agencies should realise that an appreciable part of taxpayers' money is returned to society in the form of increased profits for high-tech firms, particularly for innovative SMEs (Libaers et al., 2010): around 75\% of CERN suppliers in our sample include fewer than 250 employees. Obviously, this consideration abstracts from potential issues related to competition in supplier markets, such as concentration and market power, which should be investigated in further research.

Conceivably, in some distant future scientists and engineers may find some practical application for the Higgs boson; however, market responses to investments in science are observable on a much shorter horizon (a decade or so for the median order during the construction of the LHC). These responses are mediated by high-tech firms involved in the procurement process, and in principle, the economic impact can be quantified. Obviously, there are other important channels for the propagation of the social benefits of Big Science, such as human capital and cultural effects (Martin and Irvine, 2001; Florio et al., 2016) or technology transfer (Nielsen and Anelli, 2016). We do not claim that all large-scale research infrastructure projects can be justified by means of technological procurement spillovers alone, but it is worthwhile to record their benefits systematically and measure them against investment costs.

\section{Acknowledgments:}

The authors are very grateful to CERN and particularly to Anders Unnervik (Head of Procurement and Industrial Services) for access to LHC procurement data and to Andrea Bastianin, Emanuele Bacchiocchi and Carlo Fiorio (University of Milan) for their helpful comments. The present study was funded by a grant to the University of Milan (P.I. Massimo Florio) from the European Investment Bank Institute and by funds for postdoctoral research from the University of Milan (Paolo Castelnovo). The present findings, interpretations and conclusions should not be attributed to the European Investment Bank or any other institution. The work of Stefano Forte is partially supported by the European Union's Horizon 2020 research and innovation programme under grant agreement $\mathrm{N}^{\circ} 740006$.

\section{Appendix}

\section{Correlation matrix}

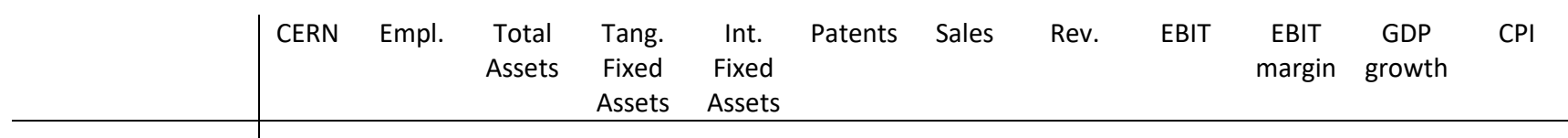




\begin{tabular}{|c|c|c|c|c|c|c|c|c|c|c|c|c|}
\hline CERN & 1.000 & & & & & & & & & & & \\
\hline Employees & 0.120 & 1.000 & & & & & & & & & & \\
\hline Total Assets & 0.115 & 0.890 & 1.000 & & & & & & & & & \\
\hline Tang. Fix. Assets & 0.032 & 0.244 & 0.388 & 1.000 & & & & & & & & \\
\hline Intang. Fix. Assets & 0.046 & 0.268 & 0.430 & 0.723 & 1.000 & & & & & & & \\
\hline Patents & 0.057 & 0.449 & 0.390 & 0.101 & 0.063 & 1.000 & & & & & & \\
\hline Sales & 0.124 & 0.960 & 0.932 & 0.365 & 0.380 & 0.450 & 1.000 & & & & & \\
\hline Revenues & 0.124 & 0.962 & 0.931 & 0.366 & 0.380 & 0.452 & 0.998 & 1.000 & & & & \\
\hline EBIT & 0.084 & 0.570 & 0.676 & 0.549 & 0.398 & 0.041 & 0.668 & 0.669 & 1.000 & & & \\
\hline EBIT margin & 0.012 & -0.006 & 0.003 & 0.039 & 0.015 & 0.020 & 0.006 & 0.005 & 0.105 & 1.000 & & \\
\hline GDP growth & 0.221 & 0.047 & 0.058 & 0.051 & 0.102 & -0.031 & 0.059 & 0.059 & 0.057 & 0.058 & 1.000 & \\
\hline CPI & 0.017 & -0.042 & -0.037 & -0.005 & -0.007 & -0.012 & -0.041 & -0.041 & -0.028 & -0.031 & -0.241 & 1.000 \\
\hline
\end{tabular}

Table Al - Impact of CERN procurement on $R \& D$ effort, $R E$ regressions

\begin{tabular}{|c|c|c|c|c|}
\hline & $\begin{array}{c}(1) \\
\Delta \mathrm{R} \& \mathrm{D}\end{array}$ & $\begin{array}{c}(2) \\
\Delta R \& D\end{array}$ & $\begin{array}{c}(3) \\
\Delta R \& D\end{array}$ & $\begin{array}{c}(4) \\
\Delta \mathrm{R} \& \mathrm{D}\end{array}$ \\
\hline CERN & $\begin{array}{c}0.575^{* * * *} \\
(0.147)\end{array}$ & $\begin{array}{c}0.741 * * * \\
(0.216)\end{array}$ & $\begin{array}{c}0.898 * * * \\
(0.189)\end{array}$ & $\begin{array}{l}0.0749 \\
(0.162)\end{array}$ \\
\hline$\Delta$ Employees $(\mathrm{mln})$ & $\begin{array}{c}-1.93 * * * \\
(0.126)\end{array}$ & $\begin{array}{c}-1.93 * * * \\
(0.130)\end{array}$ & $\begin{array}{c}-1.95 * * * \\
(0.125)\end{array}$ & $\begin{array}{c}-0.0114 \\
(0.0308)\end{array}$ \\
\hline$\Delta \mathrm{TFA} /$ Employees $(\mathrm{mln})$ & & & & $\begin{array}{c}0.0321 \\
(0.0449)\end{array}$ \\
\hline size_very_large & $\begin{array}{c}1.026 * * \\
(0.416)\end{array}$ & $\begin{array}{c}1.020 * * * \\
(0.341)\end{array}$ & $\begin{array}{c}1.129 * * * \\
(0.368)\end{array}$ & \\
\hline size_large & $\begin{array}{c}0.342 \\
(0.692)\end{array}$ & $\begin{array}{c}0.348 \\
(0.630)\end{array}$ & $\begin{array}{c}0.242 \\
(0.645)\end{array}$ & \\
\hline size_medium & $\begin{array}{c}0.137 \\
(0.736)\end{array}$ & $\begin{array}{c}0.136 \\
(0.701)\end{array}$ & $\begin{array}{l}0.0599 \\
(0.800)\end{array}$ & \\
\hline Sector & Yes & Yes & Yes & Yes \\
\hline Country & Yes & Yes & Yes & Yes \\
\hline Macro controls & Yes & Yes & Yes & Yes \\
\hline Years & No & Yes & Yes & Yes \\
\hline Years*Country & No & No & Yes & Yes \\
\hline Cons & $\begin{array}{c}-1.010 * \\
(0.563)\end{array}$ & $\begin{array}{c}-0.882 \\
(0.601)\end{array}$ & $\begin{array}{c}-2.609 * * * \\
(0.705)\end{array}$ & $\begin{array}{c}-2.777 * * * \\
(0.246)\end{array}$ \\
\hline $\mathrm{R}^{2}$ & 0.085 & 0.085 & 0.094 & 0.020 \\
\hline$N$ & 3893 & 3893 & 3893 & 3488 \\
\hline
\end{tabular}

Standard errors clustered by country in parentheses; $* p<0.10, * * p<0.05, * * * p<0.01$

Table A2 - Impact of CERN procurement on innovation output, Poisson Regressions

\begin{tabular}{|c|c|c|c|c|c|c|c|c|}
\hline & $\begin{array}{c}(1) \\
\Delta \text { Patents }\end{array}$ & $\begin{array}{c}(2) \\
\Delta \text { Patents }\end{array}$ & $\begin{array}{c}(3) \\
\Delta \text { Patents }\end{array}$ & $\begin{array}{c}(4) \\
\Delta \text { Patents }\end{array}$ & $\begin{array}{c}(5) \\
\Delta \text { Patents }\end{array}$ & $\begin{array}{c}(6) \\
\Delta \text { Patents }\end{array}$ & $\begin{array}{c}(7) \\
\Delta \text { Patents }\end{array}$ & $\begin{array}{c}(8) \\
\Delta \text { Patents }\end{array}$ \\
\hline CERN & $\begin{array}{c}0.305 \\
(0.239)\end{array}$ & $\begin{array}{c}0.493 * * \\
(0.248)\end{array}$ & $\begin{array}{c}0.485^{* *} \\
(0.211)\end{array}$ & $\begin{array}{c}0.689 * * * \\
(0.220)\end{array}$ & $\begin{array}{c}0.494 * * \\
(0.224)\end{array}$ & $\begin{array}{c}0.726 * * * \\
(0.238)\end{array}$ & $\begin{array}{c}0.482 * * \\
(0.211)\end{array}$ & $\begin{array}{c}0.685 * * * \\
(0.219)\end{array}$ \\
\hline$\Delta$ Employees (mln) & $\begin{array}{l}-0.0447 \\
(0.0289)\end{array}$ & $\begin{array}{c}-0.0803 * * \\
(0.0404)\end{array}$ & $\begin{array}{l}-0.0460 \\
(0.0294)\end{array}$ & $\begin{array}{c}-0.0874 * * \\
(0.0401)\end{array}$ & $\begin{array}{l}-0.0435 \\
(0.0296)\end{array}$ & $\begin{array}{l}-0.0811^{*} \\
(0.0430)\end{array}$ & $\begin{array}{l}-0.0463 \\
(0.0294)\end{array}$ & $\begin{array}{c}-0.0876 * * \\
(0.0440)\end{array}$ \\
\hline$\Delta$ Total Assets (bln) & & $\begin{array}{c}0.129 \\
(0.146)\end{array}$ & & $\begin{array}{c}0.150 \\
(0.191)\end{array}$ & & $\begin{array}{c}0.111 \\
(0.213)\end{array}$ & & $\begin{array}{c}0.150 \\
(0.190)\end{array}$ \\
\hline size_very_large & $\begin{array}{c}4.424 * * * \\
(1.004)\end{array}$ & & $\begin{array}{c}4.243 * * * \\
(1.004)\end{array}$ & & $\begin{array}{c}4.144 * * * \\
(1.008)\end{array}$ & & $\begin{array}{c}4.250 * * * \\
(1.004)\end{array}$ & \\
\hline size_large & $2.983 * * *$ & & $2.801 * * *$ & & $2.663 * * *$ & & $2.812 * * *$ & \\
\hline
\end{tabular}




\begin{tabular}{|c|c|c|c|c|c|c|c|c|}
\hline & $(1.003)$ & & (1.004) & & (1.009) & & $(1.005)$ & \\
\hline size_medium & $\begin{array}{c}1.458 \\
(1.010)\end{array}$ & & $\begin{array}{c}1.344 \\
(1.011)\end{array}$ & & $\begin{array}{c}1.151 \\
(1.016)\end{array}$ & & $\begin{array}{c}1.347 \\
(1.004)\end{array}$ & \\
\hline$\Delta(\mathrm{IA} / \mathrm{TA})$ & & & $\begin{array}{c}2.498 * * * \\
(0.568)\end{array}$ & $\begin{array}{c}3.852 * * * \\
(0.766)\end{array}$ & & & $\begin{array}{c}2.500 * * * \\
(0.564)\end{array}$ & $\begin{array}{c}3.857 * * * \\
(0.764)\end{array}$ \\
\hline$\Delta(\mathrm{IA} / \mathrm{TA}) \_l a g 1$ & & & & & $\begin{array}{c}0.533 \\
(1.334)\end{array}$ & $\begin{array}{c}1.261 \\
(1.864)\end{array}$ & & \\
\hline GDP_growth & $\begin{array}{c}0.0357 \\
(0.0538)\end{array}$ & $\begin{array}{c}0.0763 \\
(0.0486)\end{array}$ & $\begin{array}{c}0.0780 \\
(0.0544)\end{array}$ & $\begin{array}{l}0.122 * * \\
(0.0482)\end{array}$ & $\begin{array}{c}0.0741 \\
(0.0573)\end{array}$ & $\begin{array}{l}0.123 * * \\
(0.0498)\end{array}$ & $\begin{array}{c}0.0792 \\
(0.0541)\end{array}$ & $\begin{array}{l}0.123 * * \\
(0.0481)\end{array}$ \\
\hline Sector & Yes & Yes & Yes & Yes & Yes & Yes & Yes & Yes \\
\hline Country & Yes & Yes & Yes & Yes & Yes & Yes & Yes & Yes \\
\hline Years & Yes & Yes & Yes & Yes & Yes & Yes & Yes & Yes \\
\hline Firm fixed effects & No & No & No & No & No & No & Yes & Yes \\
\hline Cons & $\begin{array}{c}-3.924 * * * \\
(1.452)\end{array}$ & $\begin{array}{l}-1.043 \\
(1.089) \\
\end{array}$ & $\begin{array}{c}-3.727 * * * \\
(1.431)\end{array}$ & $\begin{array}{c}-1.231 \\
(1.090)\end{array}$ & $\begin{array}{l}-20.73 \\
(24.25) \\
\end{array}$ & $\begin{array}{l}-17.94 \\
(16.87)\end{array}$ & $\begin{array}{c}-3.737 * * * \\
(1.433)\end{array}$ & $\begin{array}{l}-1.233 \\
(1.091)\end{array}$ \\
\hline$N$ & 5278 & 5278 & 4660 & 4660 & 4326 & 4325 & 4660 & 4660 \\
\hline
\end{tabular}

Column (6): fixed effects controls using the Blundell et al. (1999) pre-sample mean scaling estimator.

Standard errors clustered by country in parentheses; $* p<0.10$, ** $p<0.05$, *** $p<0.01$

Table A3 - Impact of CERN procurement on productivity, RE regressions

\begin{tabular}{|c|c|c|c|c|c|c|}
\hline & $\begin{array}{c}(1) \\
\Delta \text { Productivity }\end{array}$ & $\begin{array}{c}(2) \\
\Delta \text { Productivity }\end{array}$ & $\begin{array}{c}(3) \\
\Delta \text { Productivity }\end{array}$ & $\begin{array}{c}(4) \\
\Delta \text { Productivity }\end{array}$ & $\begin{array}{c}(5) \\
\Delta \text { Productivity }\end{array}$ & $\begin{array}{c}\text { (6) } \\
\Delta \text { Productivity }\end{array}$ \\
\hline CERN & $\begin{array}{c}8.321 \\
(5.776)\end{array}$ & $\begin{array}{c}5.716 \\
(5.137)\end{array}$ & $\begin{array}{c}13.11 * * * \\
(2.057)\end{array}$ & $\begin{array}{c}9.932 * * * \\
(3.570)\end{array}$ & $\begin{array}{c}13.02 * * * \\
(2.009)\end{array}$ & $\begin{array}{c}9.773 * * * \\
(3.568)\end{array}$ \\
\hline$\Delta$ Employees $(\mathrm{mln})$ & $\begin{array}{c}-20.62 * * * \\
(1.440)\end{array}$ & $\begin{array}{c}-19.91 * * * \\
(0.789)\end{array}$ & $\begin{array}{c}-17.67 * * * \\
(1.177)\end{array}$ & $\begin{array}{c}-17.63 * * * \\
(1.369)\end{array}$ & $\begin{array}{c}-17.69 * * * \\
(1.175)\end{array}$ & $\begin{array}{c}-17.66 * * * \\
(1.379)\end{array}$ \\
\hline$\Delta$ Total Assets (bln) & $\begin{array}{c}8.607 \\
(15.00)\end{array}$ & & $\begin{array}{c}1.905 \\
(12.82)\end{array}$ & & $\begin{array}{c}1.930 \\
(12.85)\end{array}$ & \\
\hline size_very_large & & $\begin{array}{l}27.56^{*} \\
(14.07)\end{array}$ & & $\begin{array}{c}15.05 * * \\
(6.563)\end{array}$ & & $\begin{array}{c}16.06 * * * \\
(5.906)\end{array}$ \\
\hline size_large & & $\begin{array}{l}35.90^{*} \\
(20.26)\end{array}$ & & $\begin{array}{c}22.32 * * * \\
(7.445)\end{array}$ & & $\begin{array}{c}23.17 * * * \\
(7.247)\end{array}$ \\
\hline size_medium & & $\begin{array}{l}-17.83 \\
(19.41)\end{array}$ & & $\begin{array}{l}-13.97 \\
(18.81)\end{array}$ & & $\begin{array}{c}-13.24 \\
(18.56)\end{array}$ \\
\hline$\Delta \mathrm{R} \& \mathrm{D}$ & & & $\begin{array}{c}0.784 * * \\
(0.378)\end{array}$ & $\begin{array}{l}0.775^{*} \\
(0.422)\end{array}$ & $\begin{array}{c}0.776 * * \\
(0.382)\end{array}$ & $\begin{array}{l}0.767 * \\
(0.427)\end{array}$ \\
\hline$\Delta($ Patents/Empl $)$ & & & & & $\begin{array}{c}88.86 * * * \\
(24.65)\end{array}$ & $\begin{array}{c}91.68 * * * \\
(25.57)\end{array}$ \\
\hline Macro controls & Yes & Yes & Yes & Yes & Yes & Yes \\
\hline Sector & Yes & Yes & Yes & Yes & Yes & Yes \\
\hline Country & Yes & Yes & Yes & Yes & Yes & Yes \\
\hline Years & Yes & Yes & Yes & Yes & Yes & Yes \\
\hline Years*country & Yes & Yes & Yes & Yes & Yes & Yes \\
\hline Cons & $\begin{array}{c}-73.31 * * * \\
(8.725)\end{array}$ & $\begin{array}{c}-103.0 * * * \\
(24.30)\end{array}$ & $\begin{array}{c}-60.08 * * * \\
(7.813)\end{array}$ & $\begin{array}{c}-88.77 * * * \\
(17.67)\end{array}$ & $\begin{array}{c}-69.22 * * * \\
(8.971)\end{array}$ & $\begin{array}{c}-97.77 * * * \\
(17.54)\end{array}$ \\
\hline $\mathrm{R}^{2}$ & 0.338 & 0.339 & 0.379 & 0.381 & 0.379 & 0.381 \\
\hline$N$ & 3659 & 3659 & 3328 & 3328 & 3320 & 3320 \\
\hline
\end{tabular}

Standard errors clustered by country in parentheses; $* p<0.10, * * p<0.05, * * * p<0.01$

Table A4 - Impact of CERN procurement on economic outcomes: Revenues, EBIT and EBIT margin, $R E$ regressions

\begin{tabular}{lcccccc}
\hline & $(1)$ & $(2)$ & $(3)$ & $(4)$ & $(5)$ & $(6)$ \\
& $\Delta \mathrm{OR}$ & $\Delta \mathrm{OR}$ & $\Delta \mathrm{EBIT}$ & $\Delta \mathrm{EBIT}$ & $\Delta \mathrm{EBITm}$ & $\Delta \mathrm{EBITm}$ \\
\hline CERN & $29860.7^{* * *}$ & $47589.1^{* *}$ & $3387.9^{*}$ & $5012.0^{* * *}$ & $0.442^{*}$ & $0.421^{*}$ \\
& $(9280.5)$ & $(21057.3)$ & $(1782.5)$ & $(1864.0)$ & $(0.257)$ & $(0.256)$ \\
$\Delta$ Total Assets (bln) & $356622.2^{* * *}$ & & $25152.1^{* * *}$ & & -0.190 &
\end{tabular}




\begin{tabular}{|c|c|c|c|c|c|c|}
\hline size_very_large & & $\begin{array}{c}24026.0^{* * * *} \\
(6050.8)\end{array}$ & & $\begin{array}{c}560.9 \\
(1754.3)\end{array}$ & & $\begin{array}{c}1.389 \\
(0.955)\end{array}$ \\
\hline size_large & & $\begin{array}{c}-563.3 \\
(3284.9)\end{array}$ & & $\begin{array}{c}2791.8 \\
(2540.4)\end{array}$ & & $\begin{array}{l}1.428^{*} \\
(0.842)\end{array}$ \\
\hline size_medium & & $\begin{array}{l}-1561.6 \\
(2291.5)\end{array}$ & & $\begin{array}{l}1021.5 \\
(703.9)\end{array}$ & & $\begin{array}{l}1.567 \\
(0.977)\end{array}$ \\
\hline Macro controls & Yes & Yes & Yes & Yes & Yes & Yes \\
\hline Sector & Yes & Yes & Yes & Yes & Yes & Yes \\
\hline Country & Yes & Yes & Yes & Yes & Yes & Yes \\
\hline Years & Yes & Yes & Yes & Yes & Yes & Yes \\
\hline Years*country & Yes & Yes & Yes & Yes & Yes & Yes \\
\hline Cons & $\begin{array}{c}-95195.8 * * * \\
(14861.4)\end{array}$ & $\begin{array}{c}-116777.5 * * * \\
(26325.2)\end{array}$ & $\begin{array}{c}44025.1 * * * \\
(1505.7)\end{array}$ & $\begin{array}{c}44341.3 * * * \\
(2863.4)\end{array}$ & $\begin{array}{c}-9.838 * * * \\
(0.900)\end{array}$ & $\begin{array}{c}-11.18 * * * \\
(0.916)\end{array}$ \\
\hline $\mathrm{R}^{2}$ & 0.540 & 0.121 & 0.146 & 0.127 & 0.098 & 0.099 \\
\hline$N$ & 5799 & 5799 & 5812 & 5812 & 5771 & 5771 \\
\hline
\end{tabular}

Standard errors clustered by country in parentheses; $* p<0.10, * * p<0.05, * * * p<0.01$

Table A5 - Impact of CERN procurement on $R \& D$, innovation outcome and productivity, dynamic specifications

\begin{tabular}{|c|c|c|c|}
\hline & $\begin{array}{c}(1) \\
\Delta R \& D\end{array}$ & $\begin{array}{c}(2) \\
\Delta \text { Patents }\end{array}$ & $\begin{array}{c}(3) \\
\Delta \text { Productivity }\end{array}$ \\
\hline CERN & $\begin{array}{c}0.501 * * * \\
(0.166)\end{array}$ & $\begin{array}{c}0.533 * * * \\
(0.091)\end{array}$ & $\begin{array}{l}16.03 * \\
(7.558)\end{array}$ \\
\hline$\Delta \mathrm{R} \& \mathrm{D} \_l a g 1$ & $\begin{array}{c}-0.174 * * * \\
(0.017)\end{array}$ & & \\
\hline$\Delta$ Patents_lag1 & & $\begin{array}{c}0.129 * * * \\
(0.007)\end{array}$ & \\
\hline$\Delta$ Productivity_lag1 & & & $\begin{array}{c}-0.475 * * * \\
(0.137)\end{array}$ \\
\hline Firm-level controls & Yes & Yes & Yes \\
\hline Macro controls & Yes & Yes & Yes \\
\hline Country & $(\S)$ & Yes & $(\S)$ \\
\hline Sector & $(\S)$ & Yes & $(\S)$ \\
\hline Years & Yes & Yes & Yes \\
\hline Years*Country & Yes & No & Yes \\
\hline Cons & $\begin{array}{c}-0.776 * * * \\
(0.1000)\end{array}$ & $\begin{array}{c}-40.93 * * * \\
(14.49)\end{array}$ & $\begin{array}{c}73.17 * * * \\
(1.707)\end{array}$ \\
\hline $\mathrm{R}^{2}$ & 0.010 & n.a. & 0.157 \\
\hline$N$ & 2899 & 5488 & 2790 \\
\hline
\end{tabular}

Columns (1) and (3): FE regressions

(§) Country and sector fixed effects omitted in FE regressions

Column (2): Negative Binomial Regression

Standard errors clustered by country in parentheses; $* p<0.10, * * p<0.05, * * * p<0.01$

Table A6 - Impact of CERN procurement on Revenues, EBIT and EBIT margin, dynamic specifications

\begin{tabular}{|c|c|c|c|c|c|c|c|c|c|}
\hline & \multicolumn{3}{|c|}{ FULL SAMPLE } & \multicolumn{3}{|c|}{ HIGH-TECH } & \multicolumn{3}{|c|}{ NON HIGH-TECH } \\
\hline & (1) & (2) & (3) & (1) & (2) & (3) & (1) & (2) & (3) \\
\hline & $\Delta \mathrm{OR}$ & $\Delta \mathrm{EBIT}$ & $\Delta$ EBITm & $\Delta \mathrm{OR}$ & $\Delta \mathrm{EBIT}$ & $\Delta \mathrm{EBITm}$ & $\Delta \mathrm{OR}$ & $\triangle \mathrm{EBIT}$ & $\Delta \mathrm{EBITm}$ \\
\hline CERN & $\begin{array}{c}28720.5 \text { *** } \\
(6982.3)\end{array}$ & $\begin{array}{l}4019.3^{\text {** }} \\
(1838.5)\end{array}$ & $\begin{array}{c}1.064^{* * * *} \\
(0.228)\end{array}$ & $\begin{array}{c}34596.3 * * * \\
(6579.5)\end{array}$ & $\begin{array}{c}6566.8 * * \\
(2369.7)\end{array}$ & $\begin{array}{c}0.945^{* * * *} \\
(0.252)\end{array}$ & $\begin{array}{l}14937.4 * \\
(7606.7)\end{array}$ & $\begin{array}{l}-1758.9 \\
(2674.5)\end{array}$ & $\begin{array}{l}1.179 * * \\
(0.444)\end{array}$ \\
\hline$\Delta$ EBITm_lag1 & & & $\begin{array}{c}- \\
0.367 * * * \\
(0.0275)\end{array}$ & & & $\begin{array}{c}- \\
0.364 * * * \\
(0.0448)\end{array}$ & & & $\begin{array}{c}- \\
0.370 * * * \\
(0.0314)\end{array}$ \\
\hline
\end{tabular}

$\Delta \mathrm{OR} \_$lag1

$0.103 * * *$

$0.0875^{* * *}$

0.155 
$(0.0182)$

$\Delta$ EBIT_lag1

$\Delta$ Total Assets

(bln)

\begin{tabular}{|c|c|c|c|c|c|c|c|c|c|}
\hline Macro controls & Yes & Yes & Yes & Yes & Yes & Yes & Yes & Yes & Yes \\
\hline Years & Yes & Yes & Yes & Yes & Yes & Yes & Yes & Yes & Yes \\
\hline Years*Country & Yes & Yes & Yes & Yes & Yes & Yes & Yes & Yes & Yes \\
\hline Cons & $-23480 * * *$ & $-3081.5 * * *$ & $0.0632 *$ & $-9470.6^{* * * *}$ & $-1510.2 * * *$ & $1.016^{* * * *}$ & $-6459.5^{* *} *$ & $\begin{array}{c}1136.0 * * * \\
(204.2)\end{array}$ & $\begin{array}{c}- \\
1.996^{* * * *} \\
(0.100)\end{array}$ \\
\hline $\mathrm{R}^{2}$ & 0.491 & 0.117 & 0.080 & 0.599 & 0.136 & 0.040 & 0.540 & 0.538 & 0.179 \\
\hline$N$ & 5340 & 5359 & 5295 & 3406 & 3415 & 3382 & 1934 & 1944 & 1913 \\
\hline
\end{tabular}

FE regressions

Standard errors clustered by country in parentheses; $* p<0.10, * * p<0.05, * * * p<0.01$
$(0.161)$

$\begin{array}{cccccccc}-0.155^{* * *} & & & -0.159 * * * & & & -0.0895 & \\ (0.0494) & & & (0.0499) & & & (0.213) & \\ 26191.3^{* * *} & -0.0993 & 328555^{* * * *} & 24664.7 * * * & -0.180 & 927069.6^{*} & 99755.1 * * * & 2.300 \\ & & & & & & & \\ (5017.1) & (0.238) & (15337.9) & (4747.6) & (0.269) & (478396.3) & (14560.2) & (2.765)\end{array}$

$$
\text { (14777.4) (5017.1) }
$$

\section{Yes}

Yes

Yes

Yes 
Anselin L., Varga A., Acs Z. (1997). Local geographic spillovers between university research and technology innovations. Journal of Urban Economics, vol. 42(3): 422-448.

Arenius M., Boisot M. (2011). A tale of four suppliers, in Collisions and collaboration: The organization of learning in the ATLAS experiment at the LHC, Boisot M., Nordberg M., Yami S. and Nicquevert B., Oxford University Press, Oxford, chap. 8, pp. 135-159.

Arrow K. (1962) The economic implications of learning by doing, The Review of Economic Studies, vol. 29(3): $155-173$.

Aschhoff B., and Sofka W. (2009). Innovation on demand-can public procurement drive market success of innovations? Research Policy, vol. 38(8): 1235-1247.

Aschauer D., Von Aufschnaiter C., Charitos P., Drahoss E., Gutleber J., Keinz P., Kindl M., Kofler J. and Topic P. (2017). Superconductivity Challenge. Identifying new Fields of Application for Superconductors. CERN and Wirtschaftsuniversität Wien. Mimeo.

Autio E., (2014). Innovation from Big Science: Enhancing Big Science Impact Agenda, Imperial College Business School, London (https://www.gov.uk/government/uploads/system/uploads/attachment data/file/288481/bis-14-618innovation-from-big-science-enhancing-big-science-impact-agenda.pdf)

Autio E., Bianchi-Streit M. and Hameri A.P. (2003). Technology transfer and technological learning through CERN's procurement activity, CERN - Education and Technology Transfer Division

Autio E., Hameri A.P. and Vuola O. (2004). A Framework of Industrial Knowledge Spillovers in Big-Science Centers. Research Policy, vol. 33: 107-126.

Bajari P. and Tadelis S. (2001). Incentives versus transaction costs, Rand Journal of Economics, vol. 32(3): $387-407$.

Bania N., Eberts, R., Fogarty, M. (1993). Universities and the start-up of new companies. Review of Economics and Statistics, vol. 75 (4): 761-766.

Battistoni G., Genco M., Marsilio M., Pancotti C., Rossi S. and Vignetti S. (2016). Cost-benefit analysis of applied research infrastructure. Evidence from health care, Technological Forecasting and Social Change, vol. 112: 79-91.

Baum C.F., Lööf H., Nabavi P. and Stephan A. (2017). A new approach to estimation of the R\&D-innovation-productivity relationship, Economics of Innovation and New Technology, 26 (1-2): 121-133.

Bergman E.M. (1990). The economic impact of industry-funded university R\&D. Research Policy, vol. 19: 340-355.

Bernstein J.I (1988). Costs of production, intra- and interindustry R\&D spillovers: Canadian evidence. Canadian Journal of Economics, vol. 21(2): 324-347.

Bernstein J.I. and Nadiri M.I (1991). Product demand, cost of production, spillovers and the social rate of return to R\&D. NBER working paper $\mathrm{N}^{\circ} 3625$

Bezdek R.H. and Wendling R.M. (1992). Sharing Out NASA's Spoils, Nature, vol. 355: 105-106.

Bianchi-Streit M., Blackburne N., Budde R., Reitz H., Sagnell B., Schmied H. and Schorr B. (1984). Economic utility resulting from CERN contracts (second study), CERN.

Blundell R., Griffith R. and Van Reenen J. (1999). Market Share, Market Value and Innovation in a Panel of British Manufacturing Firms. Review of Economic Studies, vol. 66 (3): 529-54.

Bornmann L. (2012). Measuring the societal impact of research. EMBO reports, 13 (8), 673-676

Bornmann L. (2013). What is societal impact of research and how can it be assessed? A literature survey. Journal of the American society for information science and technology, vol. 64 (2): 217-233. 
Box G. and Jenkins G. (1970). Time Series Analysis: Forecasting and Control. San Francisco: Holden-Day.

Bresnahan T. and Trajtenberg M. (1995). General Purpose Technologies: Engines of growth? Journal of Econometrics, vol. 65 (1): 83-108

Cameron A.C. and Trivedi P.K. (2005). Microeconometrics. Methods and Applications. Cambridge University Press.

CERN (1993a). “CERN Annual report 1993.” Available online at (last accessed: March 2017): http://cds.cern.ch/record/1516861

CERN (1993b). "Report of the Finance Committee Working Group on CERN Purchasing Policy and Procedures." 98th Session of Council, 247th Meeting of Finance Committee, (CERN/2006 - CERN/FC/3662). Available online at (last accessed: March 2017): http://cds.cern.ch/record/33166.

CERN (2015). “CERN Financial Rules.” Available online at (last accessed: March 2017): https://espace.cern.ch/fpprocedures/procurement

Crépon B., Duguet E. and Mairesse J. (1998). Research, innovation, and productivity: an econometric analysis at the firm level. Economics of Innovation and New Technology, vol. 7 (2): 115-158.

Edler, J. and Georghiou, L. (2007). Public procurement and innovation. Resurrecting the demand side. Research Policy, Vol. 36(7): 949-963.

Edquist C. and Hommen L. (2000). Public technology procurement and innovation theory, in Edquist and Hommen eds (2000), Public technology procurement and innovation, Kluwer Academic Publishers, pp. 5-70

Edquist C. and Zabala-Iturriagagoitia J. M. (2012). Public procurement for innovation as mission-oriented innovation policy. Research Policy, vol. 41 (10): 1757-1769.

Edquist,C., Vonortas N.S., Zabala-Iturriagagoitia J. M. and J. Edler. (2015). Public Procurement for Innovation. Edward Elgar Publishing: Cheltenham, UK. ESFRI (2016), Strategy Report on Research Infrastructures, available at http://www.esfri.eu/roadmap-2016.

Eliasson G. (2010). Advanced Public Procurement as Industrial Policy. The Aircraft Industry as a Technical University. Springer

Eliasson G. (2011). Advanced purchasing, spillovers and innovative discovery. Journal of Evolutionary Economics, vol. 21(1): 121-139.

Evans L.R. (2009), The Large Hadron Collider: a Marvel of Technology, EPFL Press

Fahlaender C. (2016). Engaging local industry in the development of basic research infrastructure and instrumentation. The case of HIE-ISOLDE and ESS, AIP Conference Proceedings, vol. 1753(1).

Florio M., Forte S. and Sirtori E. (2016). Forecasting the socio-economic impact of the Large Hadron Collider: A costbenefit analysis to 2025 and beyond, Technological Forecasting and Social Change, vol. 112: 38-53.

Florio M., Giffoni F., Giunta A., Sirtori E. (2017). Big Science, Learning and Innovation: Evidence from CERN Procurement. Università degli studi Roma Tre, Working Paper $n^{\circ} 225$.

Foray D. (2004). The economic of knowledge, MIT press

Garcia-Montalvo J. and Raya J.M. (2016). Anàlisi cost-benefici i d'impacte econòmic del sincrotró ALBA, Nota d'Economia-Revista d'economia catalana i de sector públic, vol. 102: 115-125

Giudice G. F. (2010). A zeptospace odyssey. A journey into the physics of the LHC. Oxford University Press, Oxford.

Godin B. and Doré C. (2004). Measuring the Impacts of Science: Beyond the Economic Dimension, CSIIC Working Paper 
Granger C.W.J. and Newbold P. (1974). Spurious Regressions in Econometrics. Journal of Econometrics, vol. 2: $111-120$.

Griliches Z. (1979). Issues in Assessing the Contribution of Research and Development to Productivity Growth. Bell Journal of Economics, The RAND Corporation, vol. 10(1): 92-116.

Guerzoni M. and Raiteri E. (2015). Demand-side vs. supply-side technology policies: Hidden treatment and new empirical evidence on the policy mix. Research Policy, vol. 44 (3): 726-747.

HAL - Innovation Policy Economics (2013). Return on Investment in Large Scale Research Infrastructure. Final Report prepared for the National Research Council, Canada.

Hall B.H. and Sena V. (2017) Appropriability mechanisms, innovation, and productivity: evidence from the UK, Economics of Innovation and New Technology, 26(1-2): 42-62.

Hausman J., Hall B.H. and Griliches Z. (1984). Econometric Models for count data with an application to the patent-R\&D relationship. Econometrica, vol. 52(4): 909-938.

Hall B.H., Mairesse J. and Mohnen P. (2010). Measuring the Returns to R\&D, in Handbook of the Economics of Innovation, B. Hall and N. Rosenberg, Eds. (Elsevier), vol. 2, chap. 24, pp. 1033-1082.

Helmers C. and Overman H.G. (2017). My Precious! The Location and Diffusion of Scientific Research: Evidence from the Synchrotron Diamond Light Source. Economic Journal, vol. 127 (604): 2006-2040.

Helpman E. (1998). General Purpose Technologies and Economic Growth. MIT Press.

Irwin D.A. and Klenow P.J. (1994). Learning-by-Doing Spillovers in the Semiconductor Industry, Journal of political economy, vol.102(6): 1200-1227.

Jaffe A.B. (1989). Real Effects of Academic Research. The American Economic Review, vol. 79 (5): 957-970.

Jovanovic B. and Rousseau P. (2005). General purpose technologies, in Aghion P. and Durlauf S. (eds), Handbook of Economic Growth, vol. 1B, Elsevier.

Li X. (2012). Behind the recent surge of Chinese patenting: An institutional view. Research Policy 41 (1): $236-249$.

Libaers D., Hicks D. and Porter A.L. (2010). A taxonomy of small firm technology commercialization, Ind. and Corp. Change, vol. 25(3): 371-405.

Lööf H., Mairesse J. and Mohnen P. (2017). CDM 20 years after, Economics of Innovation and New Technology, 26(1-2): $1-5$.

Macilwain C. (2010). Science Economics: What science is really worth, Nature, vol. 465: 682-684

https://www.nature.com/news/2010/100609/full/465682a.html

Mansfield E. (1991). Academic research and industrial innovation. Research Policy, vol. 20: 1-12.

Mansfield E. (1998). Academic research and industrial innovation: an update of empirical findings. Research Policy, vol. 26: 773-776.

Mansfield E. and Lee J.Y. (1996). The modern university: contributor to industrial innovation and recipient of industrial R\&D support. Research Policy, vol. 25: 1047-1058.

Marin G. (2014). Do eco-innovations harm productivity growth through crowding out? Results of an extended CDM model for Italy. Research Policy, vol. 43 (2): 301-317.

Martin F. (1998). The economic impact of Canadian university R\&D. Research Policy, vol. 27: 677-687.

Martin B.R. and Irvine J. (1984a). CERN: Past performance and future prospects: I. CERN's position in world high-energy physics. Research Policy, vol. 13(4): 183-210. 
Martin B.R. and Irvine J. (1984b). CERN: Past performance and future prospects: II. The scientific performance of the CERN accelerators. Research Policy, vol. 13(5): 247-284.

Martin B.R. and Irvine J. (1984c). CERN: Past performance and future prospects: III. CERN and the future of world highenergy physics. Research Policy, vol. 13(6): 311-342.

Martin B.R. and Tang P. (2007). The benefits from Publicly Funded Research, SPRU Electronic Working Paper Series, Paper no. 161, University of Sussex, Brighton.

Mazzucato M. (2016). From market fixing to market-creating: a new framework for innovation policy. Industry and Innovation, vol. 23(2): 140-156.

Nadiri M. (1993). Innovations and technological spillovers. NBER Working Paper $N^{\circ} 4423$.

Nelson R. and Rosenberg N. (1994). American universities and technical advance. Research Policy, vol. 23(3): 323-348.

Nemet G.F. (2012). Subsidies for New Technologies and Knowledge Spillovers from Learning by Doing, Journal of Policy Analysis and Management, vol. 31(3): 601-622.

Newcombe R. (1999). Procurement as a learning process, in Profitable partnering in construction procurement, Ogunlana S. (ed), Taylor and Francis eBooks, Routledge.

Nielsen V. and Anelli G. (2016). Knowledge transfer at CERN. Technological Forecasting \& Social Change, vol. 112: 113120.

OECD (2014). The impacts of large research infrastructures on economic innovation and on society: case studies at CERN, OECD Tech. Report.

Pero M. (2013), RRI Governance in Research Infrastructures, Res-Agora

Pisano G. (1996). Learning-before-doing in the development of new process technology, Research Policy, vol. 25(7): 1097-1111

Price D. J. (1984). The Science / Technology Relationship, the Craft of Experimental Science and Policy for the Improvement of High Technology Innovation. Research Policy, vol. 13: 3-20.

Purton P. (2015). Big Science, What's it Worth, Science/Business Publishing Ltd, Brussels

Raimond W., Mairesse J., Mohnen P. and Palm F. (2015). Dynamic models of R\&D, innovation and productivity: Panel data evidence for Dutch and French manufacturing. European Economic Review, vol. 78: 285-306.

Romer P.M. (1990). Endogenous Technological Change. Journal of Political Economy, vol. 98 (5): S71-S102.

Rossi L. and Todesco E. (2009) Superconducting magnets, in Evans (2009), The Large Hadron Collider: a Marvel of Technology, EPFL Press.

Salter A.J. and Martin B.R. (2001). The Economic Benefits of Publicly Funded Basic Research: a Critical Review. Research Policy, vol. 30 (3), 509-532.

Scherer F.M. (1982). Inter-industry technology flows and productivity growth. Review of Economics and Statistics, vol. 64: 627-634.

Scherer F.M. (1984). Using Linked Patent and R\&D Data to Measure Interindustry Technology Flows, in Griliches Z. (ed.) (1984), R \& D, Patents, and Productivity. University of Chicago Press.

Schmied H. (1977). A study of economic utility resulting from CERN contracts. IEEE Transactions on Engineering Management, vol. (4): 125-138. 
Solow R.M. (1997). Learning from 'Learning by doing'. Lessons for economic growth. Stanford University Press

Stephan P. (1996). The Economics of Science. Journal of Economic Literature, vol. 34 (3): 1199-1235

Stokey N. (1988). Learning by doing and the introduction of new goods, Journal of Political Economy, vol. 96(4): 701717.

Terleckyj N.E. (1974). Effects of R\&D on the productivity growth of industries: an exploratory study. National Planning Association, Washington.

Terleckyj N.E. (1980). Direct and Indirect Effects of Industrial Research and Development on the Productivity Growth of Industries. In New Developments in Productivity Measurement, 1980, National Bureau of Economic Research, Inc., pp 357-386

Thompson P. (2010). Learning by Doing, Handbook of The Economics of Innovation, vol. 1: 429-476.

Turner M. S. (2015). Big science is hard but worth it, Science, vol. 348(6233): 375

Unnervik A. (2009). Lessons in big science management and contracting, in L.R. Evans (ed.), The Large Hadron Collider: A Marvel of Technology. EPFL Press: Lausanne.

Van Leeuwen G. and Mohnen P. (2017). Revisiting the Porter hypothesis: an empirical analysis of Green innovation for the Netherlands, Economics of Innovation and New Technology. 26(1-2): 63-77.

Van Noorden R. (2015). Impact of UK research revealed in 7,000 case studies. Nature, vol. 518 (7538).

Verbeek M. (2012). A Guide to Modern Econometrics. Wiley \& Sons Inc.

Webb D. and Whyte R. (2009). Economic Impact of the John Innes Centre, John Inner Centre, Edinburgh (https://www.jic.ac.uk/media/cms page media/266/DTZ2008economic impact.pdf)

Zhao R., Wu X. and Boeing P. (2017). The effect of institutional ownership on firm innovation: Evidence from Chinese listed firms. Research Policy, vol. 46(9): 1533-1551.

Zellner A. and Theil H. (1962). Three-stage least squares: simultaneous estimation of simultaneous equations. Econometrica. 30 (1): 54-78. 